\title{
A Flexible Broadband CPW-Fed Circularly Polarized Biomedical Implantable Antenna With Enhanced Axial Ratio Bandwidth
}

\author{
Sarosh Ahmad \\ Government College University, Faisalabad \\ Bilal Manzoor \\ University of Engineering and Technology Lahore \\ Salman Naseer \\ University of the Punjab Gujranwala Campus \\ Adnan Ghaffar \\ Auckland University of Technology \\ Mousa Hussein ( $\square$ mihussein@uaeu.ac.ae) \\ United Arab Emirates University
}

Research Article

Keywords: biomedical, polarized, antenna, federal communication commission

Posted Date: December 3rd, 2021

DOI: https://doi.org/10.21203/rs.3.rs-1097661/v1

License: (c) (i) This work is licensed under a Creative Commons Attribution 4.0 International License. Read Full License 


\section{Abstract}

Implantable antennas have a vital role in biomedical telemetry applications. Therefore, a compact low-profile circularly polarized biomedical implantable antenna operational in industrial, scientific, and medical (ISM) band at $2.45 \mathrm{GHz}$ is reported. The presented antenna is fed by a modified co-planar waveguide (CPW) technique to keep the size of the antenna compact. The radiating monopole consists of a slotted rectangular patch with one slot at an angle of $\mathbf{4 5}$ degree and truncated small patch on the left end of the CPW ground plane to make the antenna circularly polarized at the required frequency band. A flexible Roger Duroid RT5880 substrate $(\varepsilon r=2.2$, $\tan \delta=0.0009$ ) with the standard thickness of $0.254 \mathrm{~mm}$ is used to achieve bending abilities. The complete volume of the designed antenna is $21 \mathrm{~mm} \times 13.5 \mathrm{~mm} \times 0.254 \mathrm{~mm}(0.25 \times 0.16 \times 0.003)$. The antenna covers the bandwidth from $2.35-2.55 \mathrm{GHz}(200 \mathrm{MHz})$ in free space while from $1.63 \mathrm{GHz}$ to $2.8 \mathrm{GHz}(1.17 \mathrm{GHz})$ inside skin tissue. As the designed antenna is operational in skin tissue with larger bandwidth, the bending analysis along the $(x \& y)$-axis is also analyzed through the simulation. A good agreement between the simulation and measurements of the bended antenna is observed. The measured $-10 \mathrm{~dB}$ impedance bandwidth and the $3 \mathrm{~dB}$ axial ratio (AR) bandwidth inside skin-mimicking gel are $47.7 \%$ and $53.8 \%$, respectively at $2.45 \mathrm{GHz}$ frequency band. Finally, the specific absorption rate (SAR) values are also analyzed through simulations, and it is $0.78 \mathrm{~W} / \mathrm{kg}$ inside skin over $1 \mathrm{~g}$ of mass tissue. The proposed SAR values are less than the limit of the federal communication commission (FCC). This antenna is miniaturized and an ideal applicant for the biomedical implantable applications.

\section{Introduction}

Implantable medical devices (IMDs) are playing a significant role in enhancing the living conditions of the patients day-by-day. The telemetry system has given us many advantages by using an implantable antenna for the wireless communications between IMDs and external monitoring devices and those advantages can be in terms of high data rates and long-distance communications ${ }^{1,2}$. The schematic diagram of the implantable medical devices (IMDs) is presented in Figure 1. For the proposed model of the CP antenna, implantable medical devices (IMDs) are the key components ${ }^{3}$. The in-body antenna must be very thin in profile, should have very less values of SAR and antennas should have flexibility for human care purposes ${ }^{4}$. Therefore, during the design stages, the antenna must be compatible and flexible along with the human body. Human body tissues can interfere with the operating frequency which can damage the tissues, that's why the antenna should have broader bandwidth that can cover the required frequency band after being tested on human tissues ${ }^{5}$. The radiation properties of the CP antenna change rapidly due to the multiple layer structure of the human body. The human structure has skin, fat, bone, muscle, and blood tissues. These tissues have different dielectric properties which make it difficult for designing a biocompatible CP antenna to be utilized for the human body applications ${ }^{6}$. Many in-body $\mathrm{CP}$ antennas are designed for wireless communication at mid radio band ranges between $(402-405 \mathrm{MHz})^{7-10}$ and at ISM band ranges between $(2.4-2.48 \mathrm{GHz})^{11-16}$. A compact sized broadband antenna for the implementations in biomedical implants operating at MICS band (403 MHz) was presented ${ }^{8}$. A semi-flexible Roger 6010 substrate material was used with the thickness of $1.27 \mathrm{~mm}$. SAR values were calculated as $284.5 \mathrm{~W} / \mathrm{kg}$ over $1 \mathrm{~g}$ that is very high than our proposed design. Another ISM band biomedical antenna for implantable applications based on the Polyimide substrate was reported ${ }^{10}$. The antenna had a realized gain of $-16.8 \mathrm{~dB}$ and the operational bandwidth of $1.22 \%$. The complete area of the antenna was $25 \times 20 \mathrm{~mm}^{2}$. The realized gain and the operating bandwidth were reported as $-34.9 \mathrm{~dB}$ and $14.9 \%$ over the reported frequency. A small size in-body circularly polarized antenna with improved impedance matching for medical utilizations was presented ${ }^{17}$ The radiating patch has circular shape and there is a X-shaped slot inside the ground plane. The material used for the substrate was Rogers 3010 with a substrate height of $0.634 \mathrm{~mm}$. Because of the two-layered substrate the antenna profile is thick. But the antenna was less biocompatible to human body and has high specific absorption rate (SAR) value of about $649 \mathrm{~W} / \mathrm{kg}$ which is greater than the standard limit of IEEE/IEC 6270-1 standard over 1 $\mathrm{g}$ of mass tissue. An annular ring-shaped CP antenna with axial ratio bandwidth of $19.1 \%$ for the implants biomedical applications was reported ${ }^{18}$. This circular shaped antenna also had two layered substrates of flexible material Roger 3010 with a height of $0.635 \mathrm{~mm}$ of each layer. The antenna operated in ISM band at the frequency of $2.45 \mathrm{GHz}$ with the operating bandwidth of $8 \%$. This antenna worked in human body's muscle tissue and the SAR values were calculated $508 \mathrm{~W} / \mathrm{kg}$ that was higher than the standard limit. The peak gain of the antenna was $-17.5 \mathrm{~dB}$. Bending analysis was not discussed as well as the size of the antenna was larger than our proposed flexible implantable antenna. In another study, a CPW fed split-ring-resonator (SRR) based implantable antenna for medical telemetry utilizations was depicted ${ }^{19}$. The total area of the antenna was $24 \times 22 \mathrm{~mm}^{2}$ and the flexible material used for the substrate was Polyimide with a $0.07 \mathrm{~mm}$-thickness. The antenna has low-profile and appropriate for in-vitro testing. The antenna's size is still large as compared to our designed antenna. The realized gain of the antenna and the total operational bandwidth were reported as $-19.7 \mathrm{~dB}$ and $24.4 \%$ at $2.45 \mathrm{GHz}$, correspondingly. The performance comparison of the proposed antenna with recent work is depicted in Table 1. 
This article describes a circularly polarized flexible implantable antenna for the biomedical applications operating in ISM band at 2.45 $\mathrm{GHz}$, and size of $21 \times 13.5 \times 0.254 \mathrm{~mm}^{3}\left(0.25 \lambda_{g} \times 0.16 \lambda_{g} \times 0.003 \lambda_{g}\right)$. The design employs a Rogers RT5880 flexible substrate $\left(\left(\varepsilon_{r}=2.2\right.\right.$, $\tan \delta=0.0009$ ). At $2.45 \mathrm{GHz}$, and the antenna's radiation pattern is elliptical in E-plane and omni-directional in $H$-plane. The implantable antenna has small size, and it is flexible for the human body for better performance. The proposed-antenna is configured with a modified coplanar waveguide (CPW) technique, so its response to the greater bandwidth and reduced antenna back-radiation. Dimensions of the antenna is small, and was constructed and investigated by physical layers, for example, the crust of the external body and its corresponding dielectric properties, electrical conductivity, weight, and important parameters of the antenna like reflection coefficient, farfield, SAR and realized gain are calculated in this article. To make it bendable, a flexible material is used as a substrate. It should also be kept in mind that bending of the antenna must have an insignificant outcome on the performance inside human tissues when tested. The designed antenna is simulated and tested in the closeness of the human tissues. For instance, the area of the skin phantom is kept $50 \times 50 \mathrm{~mm}^{2}$. Because of the novel modified patch and the CPW, the proposed antenna covers the more bandwidth at $2.45 \mathrm{GHz}$ and the peak gain of the antenna is comparable with the previous research. Fundamentally, the efficiency and designed antenna's performance under an influence of the physical body are improved and SAR values are significantly reduced. This paper comprises the introduction of the research work that covers the background of the proposed research, statement of the problem, objectives and the significance of the research. It also covers the design analysis of the proposed antenna and highlights the fabrication and measurements result as well as testing of the antenna inside skin tissue, and describes the conclusion at the end.

\section{Antenna Design Analysis}

A compact size printed monopole antenna is proposed with a slotted rectangular-shaped radiator and fed by a modified co-planar waveguide (CPW) technique. The presented antenna contains distinct layers such as a CPW ground plane, a low-profile $0.254 \mathrm{~mm}$-thick flexible Roger RT5880 substrate $(\varepsilon r=2.2$ and $\tan \delta=0.0009$ ) and a printed monopole (from bottom to top), as shown in Figure 2 . The complete volume of the antenna is $21 \times 13.5 \times 0.254 \mathrm{~mm}^{3}\left(0.24 \lambda_{g} \times 0.16 \lambda_{g} \times 0.003 \lambda_{g}\right)$. The reported antenna is simulated in high frequency structure simulator (HFSS) software and the $S_{11}$ of the antenna is found to be $-29.8 \mathrm{~dB}$ at the working frequency of $2.45 \mathrm{GHz}$. The operating bandwidth and the axial ratio bandwidth of the designed antenna seems to be $5.73 \%$ and $47.3 \%$, respectively. The optimized values of this antenna are summarized in Table 2.

The design procedure of the implantable antenna is explained as follows:

The basic antenna design (ANT I in Figure 3(a)) contains a 50- $\Omega$ CPW feedline, a rectangular printed monopole. The monopole's width and length are calculated using (1) and (2) ${ }^{12}$, as follows:

$$
W m=\frac{\lambda_{o}}{2\left(\sqrt{0.5\left(\epsilon_{r}+1\right)}\right.}(1)
$$

Where $\epsilon_{r}$ and $\lambda_{o}$ are the relative permittivity and the wavelength of the substrate in free space at the operating frequency. The best choice of ' $\mathrm{Wm}$ ' leads to the perfect impedance matching. The length of the monopole can be evaluated by using equation (2):

$$
L m=\frac{c_{o}}{2 f_{o} \sqrt{\epsilon_{e f f}}}-2 \Delta L_{m}(2)
$$

where $\mathrm{Wm}$ and $\mathrm{Lm}$ are the width and length of the monopole antenna, $C_{O^{\prime}} \Delta L_{m^{\prime}}$ and $\epsilon_{\text {eff }}$ are the velocity of light, change in the length of the monopole due to its fringing effect, and the effective dielectric constant, respectively. The effective relative permittivity can be calculated using equation (3):

$$
\epsilon_{e f f}=\frac{\epsilon_{r}+1}{2}+\frac{\epsilon_{r}-1}{2}\left(\frac{1}{\sqrt{1+12 \frac{t s}{W_{m}}}}\right)
$$

where ts is the thickness of the substrate. At the end, the fringing effect can be calculated using equation (4): 


$$
\Delta L m=0.421 t_{s} \frac{\left(\epsilon_{\text {eff }}+0.300\right)\left(\frac{W_{m}}{t s}+0.264\right)}{\left(\epsilon_{\text {eff }}-0.258\right)\left(\frac{W_{m}}{t s}+0.813\right)}(4)
$$

with the placement of $\epsilon_{r}=2.2$, ts $=0.254 \mathrm{~mm}$ in (1)-(4), the initial parameters of the rectangular printed monopole are ' $2 m^{\prime}$ and ' $W m^{\prime}$ '. Upon full wave optimization, the width and length of the patch are $L m=10 \mathrm{~mm}$ and $W m=9.9 \mathrm{~mm}$.

\section{Proposed Antenna Design Steps}

The design steps for the printed monopole antenna are shown in Figure 3. ANT I is the basic rectangular shaped radiator with -10 dB reflection coefficient but in this instance, the antenna is resonating only at $3 \mathrm{GHz}$ frequency without showing any circular polarization. ' $\mathrm{Lm}^{\prime}$ 'and ' $\mathrm{Wm}$ ' are the radiating monopole's length and width $\left(10 \times 9.9 \mathrm{~mm}^{2}\right)$. Then, to shift the frequency towards the proposed band and to make the antenna $\mathrm{CP}$, a rectangular monopole is slotted from its top and bottom edges, as described in ANT II (Figure 3(b)). This shifts the resonating frequency from $3 \mathrm{GHz}$ to $2.7 \mathrm{GHz}(300 \mathrm{MHz})$ and keep its $S_{11}$ value below $-10 \mathrm{~dB}$ at $2.55 \mathrm{GHz}$ with axial ratio bandwidth of $5.3 \%$. Now, in the third case (ANT III), another horizontal slot is introduced in the bottom side of the radiator and the frequency shifted from $2.7 \mathrm{GHz}$ to $2.6 \mathrm{GHz}(100 \mathrm{MHz})$ and the $\mathrm{CP}$ behavior at $2.55 \mathrm{GHz}$. Therefore, to move the frequency band towards lower frequency (at $2.45 \mathrm{GHz}$ ) with good axial ratio, another horizontal slot at an angle of 45 degree and truncated short patch at the edge of the CPW ground plane are introduced as can be seen in ANT IV. Since, in the case of ANT IV, the printed monopole antenna shows axial ratio bandwidth of $47.3 \%$ and operating perfectly at $2.45 \mathrm{GHz}$ with good impedance bandwidth. Simulated $\mathrm{S}_{11}$ of all the design steps are compared in Figure 3 (e), indicating the ease of impedance tuning at $2.45 \mathrm{GHz}$ using the $\mathrm{CPW}$ technique. While the axial ratio comparison graph is shown in Figure 3(f).

\section{Parametric Study Of The Antenna}

The analysis of parameters of the implantable antenna is fully explained in this section. The reflection coefficient at $2.45 \mathrm{GHz}$ can be adjusted by varying the values of the important parameters such as width of the upper horizontal slot in monopole ' $W 1$ ', width of the feedline ' $w f$ ', width of the CPW ground ' $W g$ ', length of the upper slot in monopole ' 22 ', length of the CPW ground plane ' $I g$ ', length of the horizontal rotated slot ' $G$ ' as presented in Figure 4. Figure 4(a) illustrates that by decreasing the value of ' $W 1$ 'from $4 \mathrm{~mm}$ to $6 \mathrm{~mm}$, the frequency band shifted from $2.6 \mathrm{GHz}$ to $2.45 \mathrm{GHz}(150 \mathrm{MHz})$. When the value of the 'Wf' is changed from $7 \mathrm{~mm}$ to $9 \mathrm{~mm}$ then the frequency band shifted from $2.2 \mathrm{GHz}$ to $2.63 \mathrm{GHz}(430 \mathrm{MHz})$ as presented in Figure 4(b). From Figure 4(c), It is also noticed that when the values of the ' $W g^{\prime}$ varied from $1 \mathrm{~mm}$ to $3 \mathrm{~mm}$ then the frequency band decreased from $2.45 \mathrm{GHz}$ to $2.39 \mathrm{GHz}(60 \mathrm{MHz})$. Again, when the value of ' 2 ' ' is varied from $0.254 \mathrm{~mm}$ to $1 \mathrm{~mm}$ then there is a shift in the frequency from $2.45 \mathrm{GHz}$ to $2.6 \mathrm{GHz}(150 \mathrm{MHz})$ as shown in Figure 4(d). By increasing the value of the ' $/ g^{\prime}$ 'from $7 \mathrm{~mm}$ to $9 \mathrm{~mm}$, the band moved from $2.45 \mathrm{GHz}$ to $2.82 \mathrm{GHz}$ ( $370 \mathrm{MHz}$ ) as described in Figure $4(\mathrm{e})$. By changing the value of the slot ' $G$ ' from $4 \mathrm{~mm}$ to $6 \mathrm{~mm}$ the frequency has been shifted from $2.8 \mathrm{GHz}$ to $2.4 \mathrm{GHz}(400 \mathrm{MHz})$ (see Figure 4(f)).

\section{Fabricated Prototype Of The Proposed Antenna}

The designed biomedical implantable monopole antenna is fabricated on a flexible Roger RT5880 substrate of thickness $0.254 \mathrm{~mm}$, the front and back views of the manufactured prototype is shown in Figure 5. The radiation pattern is evaluated in an anechoic chamber and its evaluation setup is presented in Figure 5(c). In the farfield evaluation chamber, we have a proposed printed antenna and radiofrequency (RF) absorbers are used to absorb RF signals from the antenna inside chamber. A vector network analyzer (VNA) is used to check the $S_{11}$ of the implantable antenna. In the case of the simulated results, the designed antenna covers the bandwidths from 2.39$2.53(140 \mathrm{MHz})$ at $2.45 \mathrm{GHz}$, while in the case of measured reflection coefficient, the antenna covers the bandwidths from $2.35-2.55 \mathrm{GHz}$ $(200 \mathrm{MHz})$ at 2.45 as shown in Figure 6.

The ( $E \& H$ )-planes of the antenna are simulated and measured in free space (see Figure 7). The two-dimensional (2D) radiation pattern describes the behavior of the antenna. The designed antenna behaves as an elliptical shaped pattern along $E$-plane while the omnidirectional radiation pattern along $H$-plane at $2.45 \mathrm{GHz}$ frequency band. The simulated and measured gain of the designed antenna are calculated to be $-2.5 \mathrm{~dB}$ and $-2.7 \mathrm{~dB}$ at $2.45 \mathrm{GHz}$. The current density of the implantable antenna is shown in Figure 7(b). The current mainly flows around the coplanar waveguide (CPW) feedline, ground plane and the lower slots. Since, the current is flowing throughout the printed monopole in a circular pattern to show the circular polarization behavior. The comparison of the simulated and measured axial ratio and the peak gain graph is illustrated in Figure 8. From the table and the graph, it can be clearly seen that the simulated

Page $4 / 21$ 
antenna covers the axial ratio bandwidth in free space from $1.83 \mathrm{GHz}$ to $3 \mathrm{GHz}(47.3 \%)$ at $2.45 \mathrm{GHz}$ while the fabricated antenna featured axial ratio bandwidth from $1.95 \mathrm{GHz}$ to $2.83 \mathrm{GHz}(35.9 \%)$ at $2.45 \mathrm{GHz}$ as presented in Table 3.

\section{Bending Analysis Of The Flexible Antenna}

Since, the antenna is made up of a flexible Roger RT5880 substrate therefore it is necessary to check the bending analysis of the antenna along horizontal and vertical axis to validate the $S_{11}$ of the antenna when it is in unbent condition. The antenna in implantable situations depends on the twisting while in practice. In this section, the bending analysis of the antenna along $\mathrm{x}$-axis and $\mathrm{y}$-axis in free space are fully explained. The bending analysis are not only simulated but also experimentally validated using a cylindrical foam of radius $30 \mathrm{~mm}$.

\section{Bending Along X-axis}

Unlike twisting radii (bending along $\mathrm{x}$-axis ' $\mathrm{Bx}$ ' $=20 \mathrm{~mm}$ to $100 \mathrm{~mm}$ ) are selected along $\mathrm{x}$-direction to study the $S_{11}$ behavior, peak gain, and farfield of the antenna. The simulated results of the antenna are compared in Figure 9 (a), when it is bent along the $x$-axis. It is wellknown that there are unnecessary changes in all twisting radii and there is a slide reduction in the gain obtained with the radiation pattern at $2.45 \mathrm{GHz}$. While the comparison in the axial ratio of the bended antenna along $x$-axis is shown in Figure 9 (b). From the graph, it is clear that there is a minor difference in the values of the axial ratio when it is bent along $\mathrm{x}$-axis. Its axial ratio value is below $3 \mathrm{~dB}$ as well as it is perfectly resonating at $2.45 \mathrm{GHz}$.

The proposed biomedical implantable monopole printed antenna's reflection coefficient is not only simulated but also measured when it is bent along $\mathrm{x}$-axis. Figure 10 indicates the comparison between simulated and measured $S_{11}$ when bent along $\mathrm{x}$-axis $(\mathrm{Bx}=30 \mathrm{~mm})$. In the case of the simulated result, the bent antenna covers the bandwidths from $2.38-2.53 \mathrm{GHz}(150 \mathrm{MHz})$ at $2.45 \mathrm{GHz}$, while in the case of measured $S_{11}$, the antenna covers the bandwidths from $2.43-2.49 \mathrm{GHz}(60 \mathrm{MHz})$ at $2.45 \mathrm{GHz}$.

Figure 11 illustrates the simulation and measurement results of the radiation pattern along $(E \& H)$-plane in free space when the flexible antenna is bent along $x$-axis. The $2 \mathrm{D}$ radiation pattern describes the behavior of the antenna. The reported antenna behaves as an elliptical shaped pattern along $E$-plane while the omni-directional radiation features along $\mathrm{H}$-plane at $2.45 \mathrm{GHz}$ frequency band. During bending analysis along $\mathrm{x}$-axis at $\mathrm{Bx}=30 \mathrm{~mm}$, we noticed the simulated peak gain of the antenna is $-2.14 \mathrm{~dB}$ while the measured gain of $-2.3 \mathrm{~dB}$.

\section{Bending Along Y-axis}

Different values of the twisting radii (bending along y-axis 'By' $=20 \mathrm{~mm}$ to $100 \mathrm{~mm}$ ) are taken along y-axis to validate the $S_{11}$ behavior, realized gain, and radiation pattern of the antenna. The simulation outcomes of the antenna are compared in Figure 12 (a) when it is bent along the $y$-axis. There are minor changes in all twisting radii and there is a slide reduction in the gain obtained with the radiation pattern at $2.45 \mathrm{GHz}$. While the comparison in the axial ratio of the bended antenna along y-axis is shown in Figure 12 (b). From the graph, it is clear that there is a minor difference in the values of the axial ratio when it is bent along $y$-axis. Its axial ratio value is below $3 \mathrm{~dB}$ as well as it is perfectly operating at $2.45 \mathrm{GHz}$.

The proposed flexible implantable antenna's $S_{11}$ is simulated as well as measured when it is bent along y-axis. Figure 13 demonstrates the contrast of the simulated and measured $S_{11}$ when bent along y-axis $(\mathrm{By}=30 \mathrm{~mm})$. In the case of the simulated result, the bent antenna covers the bandwidths from $2.39-2.52 \mathrm{GHz}(130 \mathrm{MHz})$ at $2.45 \mathrm{GHz}$, while in the case of measured result, the antenna covers the bandwidths from $2.40-2.49 \mathrm{GHz}(90 \mathrm{MHz})$ at $2.45 \mathrm{GHz}$.

Figure 14 illustrates the simulation and measurement results of the radiation pattern along $(E \& H)$-plane in free space when the flexible antenna is bent along $y$-axis. The 2D radiation pattern describes the behavior of the antenna. The proposed antenna behaves as an elliptical shaped pattern along E-plane while the omni-directional radiation properties along $\mathrm{H}$-plane at $2.45 \mathrm{GHz}$ frequency band. During bending analysis along y-axis, we noticed the simulated antenna's peak gain is $-2.12 \mathrm{~dB}$ and the measured peak gain of $-2.35 \mathrm{~dB}$.

\section{Testing Inside Skin}

To explore the appropriateness of the antenna inside skin tissue for biomedical telemetry applications, the proposed design is simulated and tested in human body phantom like skin, in this section. Consequently, to design an antenna for the applications in biotelemetry that had high precision and the presence of the human skin phantom must take into consideration while calculating SAR. For that the antenna 
performance in proximity of human skin phantom and the SAR values at $2.45 \mathrm{GHz}$ are also evaluated. The area of the skin phantom box is $50 \times 50 \mathrm{~mm}^{2}$ as can be seen in Figure 15. HFSS software is used for simulating the proposed antenna. In an ideal case, in-body antennas should be planned to avoid the significant coupling effects from the human tissue. In order to measure the radiation pattern and scattering parameters of the printed monopole implantable antenna inside Skin, a 'Skin-Mimicking Gel' with $\epsilon_{r}$ of 46 is used (see Figure 16)), as its properties are very closed to human skin tissue.

The contrast between the simulated and measured $S_{11}$ of the antenna inside skin is described in Figure 17. The simulated $S_{11}$ inside the skin indicate that the biomedical antenna operates from $1.6 \mathrm{GHz}$ to $2.75 \mathrm{GHz}(46.9 \%)$ at $2.45 \mathrm{GHz}$ while the fabricated antenna inside mimicking gel, on the other side, featured bandwidths from $1.63 \mathrm{GHz}$ to $2.8 \mathrm{GHz}(47.7 \%)$. This proves that both simulated and measured results have good agreement among each other.

Figure 18 presents the $(E \& H)$-plane of the simulation and measurement results of the radiation pattern inside skin tissue. The 2D radiation pattern describes the behavior of the antenna inside skin. These far field results prove that the antenna inside skin has broadsided omni-directional radiation pattern along E-plane while the elliptical radiation pattern along $H$-plane at $2.45 \mathrm{GHz}$ frequency band. The simulated realized gain value inside skin is found to be $-13.8 \mathrm{~dB}$ at $2.45 \mathrm{GHz}$, whereas measurement results give the realized gain of $-15.3 \mathrm{~dB}$ at $2.45 \mathrm{GHz}$. The simulated and measured axial ratio and realized gain graph is shown in Figure 19 and their values are illustrated in Table 4. It can be noticed that the simulated antenna inside skin tissue covers the axial ratio bandwidth from $1.75 \mathrm{GHz}$ to 3.1 $\mathrm{GHz}(55.1 \%)$ at $2.45 \mathrm{GHz}$ while the fabricated antenna inside skin-mimicking gel featured axial ratio bandwidth from $1.68 \mathrm{GHz}$ to $3 \mathrm{GHz}$ $(53.8 \%)$ at $2.45 \mathrm{GHz}$.

\section{Specific Absorption Rate (Sar)}

The radiations of electromagnetic waves may cause health risks to human body and such risks are calculated in terms of SAR. The relationship between the input power and the SAR is as follows ${ }^{10}$ :

$\mathrm{SAR}=\frac{\sigma\left|E^{2}\right|}{\rho}(5)$

where ' $\sigma^{\prime}$ and' $\rho^{\prime}$ denotes the thermal conductivity $(\mathrm{S} / \mathrm{m})$ and the mass density $\left(\mathrm{kg} / \mathrm{m}^{3}\right)$, while $\mathrm{E}$ is the electric field intensity $(\mathrm{V} / \mathrm{m})$. The electric power intensity is related to the signal power as below ${ }^{13}$ :

Power $\left(\mathrm{W} / \mathrm{m}^{2}\right)=\frac{(\mathrm{E}(\mathrm{V} / \mathrm{m}))^{2}}{377}(6)$

SAR simulations were accomplished when the proposed antenna is kept inside skin. Input power Pin is kept constant at $0.5 \mathrm{~W}$ with the SAR evaluated based on the IEEE/IEC $6270-1$ standard, averaged over $1 \mathrm{~g}$ of mass tissue. SAR values calculated at $2.45 \mathrm{GHz}$ is 0.78 W/kg inside skin tissue as presented in Figure 20.

\section{Conclusion}

This paper provides a low-profile ISM band compact size printed monopole antenna for the applications in biomedical implants. The presented antenna is simulated by high frequency structure simulator (HFSS) software. This proposed antenna resonates in ISM Band at $2.45 \mathrm{GHz}$. The antenna is designed on a flexible material of RT/Duroid $5880\left(\epsilon_{\mathrm{r}}=2.2\right.$, $\left.\tan \delta=0.0009\right)$ with complete dimensions of $21 \mathrm{~mm}$ $\times 13.5 \mathrm{~mm} \times 0.254 \mathrm{~mm}$. The measured gain of the antenna inside skin-mimicking gel is calculated as $-15.8 \mathrm{~dB}$, while the measured bandwidth of the antenna reported is $47.7 \%$ inside skin tissue, respectively and the axial ratio bandwidths experimentally calculated as $53.8 \%$ inside mimicking gel. The SAR values are found to be less than FCC standards which is $0.78 \mathrm{~W} / \mathrm{kg}$ inside skin tissue. Problems of compliance with biocompatibility and safety related to the construction of medical applications were also discussed. This antenna is miniaturized and an ideal applicant for in-body biomedical applications. Furthermore, we will try to improve the impedance bandwidth of the proposed antenna so that both axial ratio and impedance bandwidth will be in close contact with each other.

Received: XX June 2021; Accepted: XX March 2021;

Published: $x x x x x x x x$

\section{Declarations}

Page 6/21 
Acknowledgements

Author contributions

S.A. wrote the paper and conceived the experiment, B.M., S.N., and A.G. conducted the experiment, and M.H., provided the funding. All authors reviewed the manuscript.

\section{Competing interests}

The authors declare no competing interests.

Additional information

Correspondence and requests for materials should be addressed to K.W.K.

Reprints and permissions information is available at www.nature.com/reprints.

Publisher's note Springer Nature remains neutral with regard to jurisdictional claims in published maps and institutional affiliations.

Open Access This article is licensed under a Creative Commons Attribution 4.0 International License, which permits use, sharing, adaptation, distribution and reproduction in any medium or format, as long as you give appropriate credit to the original author(s) and the source, provide a link to the Creative Commons license, and indicate if changes were made. The images or other third-party material in this article are included in the article's Creative Commons license, unless indicated otherwise in a credit line to the material. If material is not included in the article's Creative Commons license and your intended use is not permitted by statutory regulation or exceeds the permitted use, you will need to obtain permission directly from the copyright holder. To view a copy of this license, visit

http://creativecommons.org/licenses/by/4.0/.

(C) The Author(s) 2021

\section{References}

1. Yousaf, M. et al. "An Ultra-Miniaturized Antenna with Ultra-Wide Bandwidth Characteristics for Medical Implant Systems,". IEEE Access, 9, 40086-40097 (2021).

2. Hayat, S., Shah, S. A. A. \& Yoo, H. Miniaturized Dual-Band Circularly Polarized Implantable Antenna for Capsule Endoscopic System,. IEEE Transactions on Antennas and Propagation, 69 (4), 1885-1895 (2021).

3. Nguyen, D., Seo, C. \& “ An Ultra-Miniaturized Antenna Using Loading Circuit Method for Medical Implant Applications". IEEE Access,", 9, 111890-111898 (2021).

4. Kaim, V. et al. Ultra-Miniature Circularly Polarized CPW-Fed Implantable Antenna Design and its Validation for Biotelemetry Applications. Sci Rep, 10, 6795 (2020).

5. Singh, M. S., Ghosh, J. \& Ghosh, S. "Miniaturized Dual-Antenna System for Implantable Biotelemetry Application". IEEE Antennas and Wireless Propagation Letters, 20 (8), 1394-1398 (2021).

6. Xia, Z. et al. "A Wideband Circularly Polarized Implantable Patch Antenna for ISM Band Biomedical Applications,". IEEE Transactions on Antennas and Propagation, 68 (3), 2399-2404 (2020).

7. Karacolak, T., Hood, A. Z. \& Topsakal, E. Design of a Dual-Band Implantable Antenna and Development of Skin Mimicking Gels for Continuous Glucose Monitoring,. IEEE Transactions on Microwave Theory and Techniques, 56 (4), 1001-1008 (2008).

8. Li, R., Li, B., Du, G., Sun, X., Sun, H. \& “ A compact broadband antenna with dual-resonance for implantable devices., ” Micromachines, 10 (1), 59 (2019).

9. Liu, Y., Chen, Y., Lin, H. \& Juwono, F. H. "A Novel Differentially Fed Compact Dual-Band Implantable Antenna for Biotelemetry Applications,". IEEE Antennas and Wireless Propagation Letters, 15, 1791-1794 (2016).

10. Naik, K. K. Seelam Chaithanya Satya Teja, Bokkisam Venkata Sailaja, and Pasumarthi Amala Sri, "Design of Flexible Parasitic Element Patch Antenna for Biomedical Application," Progress in Electromagnetics Research M, 94,143-153(2020)

11. Loktongbam, P., Pal, D., Koley, C. \& “ Design of an implantable antenna for biotelemetry applications., " Microsystem Technology, 26, 2217-2226 (2020) 
12. Ganeshwaran, N., Jeyaprakash, J. K., Alsath, M. G. N. \& Sathyanarayanan, V. Design of a Dual-Band Circular Implantable Antenna for Biomedical Applications., " IEEE Antennas and Wireless Propagation Letters, 19 (1), 119-123 (2020).

13. Lei, W., Chu, H. \& Guo, Y. Design of a Circularly Polarized Ground Radiation Antenna for Biomedical Applications,. IEEE Transactions on Antennas and Propagation, 64 (6), 2535-2540 (2016).

14. Gupta, V. K. \& Thakur, D. Design and performance analysis of a CPW-fed circularly polarized implantable antenna for $2.45 \mathrm{GHz}$ ISM band. Microwave and Optical Technology Letters, 62 (12), 3952-3959 (2020).

15. Shekhawat, S., Gunaram, Sharma, V. \& Bhatnagar, D. "CPW fed implantable elliptical patch antenna for biomedical application,” AIP Conference Proceedings. 2220, 130068 (2020)

16. Luo, L. et al. Compact dual-band antenna with slotted ground for implantable applications., " Microwave and Optical Technology Letters, 61 (5), 1314-1319 (2019).

17. Xu, L., Xu, J., Chu, Z., Liu, S. \& Zhu, X. Circularly Polarized Implantable Antenna with Improved Impedance Matching,. IEEE Antennas and Wireless Propagation Letters, 19 (5), 876-880 (2020).

18. Xu, L., Bo, Y., Lu, W., Zhu, L. \& Guo, C. Circularly Polarized Annular Ring Antenna with Wide Axial-Ratio Bandwidth for Biomedical Applications,. IEEE Access, 7, 59999-60009 (2019).

19. Ketavath, K. \& Naik Dattatreya Gopi, and Sriram Sandhya Rani. "In-vitro test of miniaturized CPW-fed implantable conformal patch antenna at ISM band for biomedical applications,". IEEE Access, 7, 43547-43554 (2019).

\section{Tables}


Table 1

Performance comparison of the proposed antenna with recent work.

\begin{tabular}{|c|c|c|c|c|c|c|c|c|}
\hline $\begin{array}{l}\text { Ref. } \\
\text { No. }\end{array}$ & $\begin{array}{l}\text { Dimensions } \\
\left(\mathrm{mm}^{3}\right) /\left(\lambda_{\mathrm{g}}\right. \\
\left.\mid \operatorname{varvec} \lambda_{\mid \operatorname{varvec}}{ }^{3}\right)\end{array}$ & $\begin{array}{l}\text { Operating } \\
\text { Frequency } \\
(\mathrm{GHz})\end{array}$ & $\begin{array}{l}\text { Substrate Material } \\
\left(\varepsilon_{\mathrm{r}}\right) \\
\left.\text { (varvec } \epsilon_{\mid \text {varvecr }}\right)\end{array}$ & $\begin{array}{l}\text { Realized } \\
\text { Gain } \\
\text { (dB) }\end{array}$ & $\begin{array}{l}\text { Imp. } \\
\text { BW } \\
(\%) / \\
\text { AR } \\
\text { BW } \\
(\%)\end{array}$ & $\begin{array}{l}\text { Polarization/ } \\
\text { Antenna Type }\end{array}$ & $\begin{array}{l}\text { Human } \\
\text { Tissue } \\
\text { Enclosure }\end{array}$ & $\begin{array}{l}\text { SAR } \\
\text { (W/kg) } \\
\text { @ 1g }\end{array}$ \\
\hline [7] & $\begin{array}{l}(22.5 \times 22.5 \times 2.5) \\
(0.59 \times 0.59 \times 0.065)\end{array}$ & $\begin{array}{l}0.403 \& \\
2.45\end{array}$ & $\begin{array}{l}\text { Roger } 3210 \\
(10.2)\end{array}$ & $\begin{array}{l}-26 / \\
-15\end{array}$ & $\begin{array}{l}35.3 \\
\& 7.1\end{array}$ & $\begin{array}{l}\text { Linear/ } \\
\text { Zig-Zag Patch }\end{array}$ & SKIN & $\begin{array}{l}\text { Not } \\
\text { Calculated }\end{array}$ \\
\hline [8] & $\begin{array}{l}(23 \times 16.4 \times 1.27) \\
(0.098 \times 0.070 \times 0.005)\end{array}$ & 0.402 & $\begin{array}{l}\text { Roger } 6010 \\
(10.2)\end{array}$ & -34.9 & 12.9 & Linear/PIFA & SKIN & 284.5 \\
\hline [9] & $\begin{array}{l}(22 \times 23 \times 1.27) \\
(0.57 \times 0.6 \times 0.033)\end{array}$ & $\begin{array}{l}0.402 \& \\
2.4\end{array}$ & $\begin{array}{l}\text { Roger } 3010 \\
(10.2)\end{array}$ & $\begin{array}{l}-36.7 / \\
-27.1\end{array}$ & $\begin{array}{l}7.4 \& \\
6.6\end{array}$ & $\begin{array}{l}\text { Linear/ } \\
\text { Slotted Patch }\end{array}$ & SKIN & $\begin{array}{l}832 / \\
690\end{array}$ \\
\hline [10] & $\begin{array}{l}(25 \times 20 \times 0.07) \\
(0.34 \times 0.27 \times 0.00095)\end{array}$ & 2.45 & $\begin{array}{l}\text { Polyimide } \\
(2.78)\end{array}$ & -16.8 & 1.22 & $\begin{array}{l}\text { Linear/ } \\
\text { Printed Patch }\end{array}$ & SKIN & 1.0 \\
\hline [11] & $\begin{array}{l}(15 \times 21.5 \times 1.5748) \\
(0.39 \times 0.56 \times 0.039)\end{array}$ & 2.45 & $\begin{array}{l}\text { Roger } 3210 \\
(10.2)\end{array}$ & $<-15$ & 3.2 & $\begin{array}{l}\text { Linear/ } \\
\text { Square Patch }\end{array}$ & SKIN & $\begin{array}{l}\text { Not } \\
\text { Calculated }\end{array}$ \\
\hline [12] & $\begin{array}{l}(3.14 \times 100 \times 2.54) \\
(0.082 \times 2.6 \times 0.066)\end{array}$ & $0.4 / 2.45$ & $\begin{array}{l}\text { Roger } 6010 \\
(10.2)\end{array}$ & $\begin{array}{l}-33.1 / \\
-14.55\end{array}$ & $\begin{array}{l}38.1 \\
\& \\
17.6\end{array}$ & $\begin{array}{l}\text { Linear/ } \\
\text { Circular Patch }\end{array}$ & SKIN & $\begin{array}{l}241.5 / \\
149.7\end{array}$ \\
\hline [13] & $\begin{array}{l}(10.4 \times 10.4 \times 0.508) \\
(0.145 \times 0.145 \times 0.007)\end{array}$ & 2.45 & $\begin{array}{l}\text { Taconic } \\
(2.95)\end{array}$ & -34 & $\begin{array}{l}16.3 \\
/ \\
15.1\end{array}$ & $\begin{array}{l}\text { Circular/ } \\
\text { Printed } \\
\text { Monopole }\end{array}$ & SKIN & 356.4 \\
\hline [14] & $\begin{array}{l}(14 \times 14 \times 0.5) \\
(0.365 \times 0.365 \times 0.013)\end{array}$ & 2.45 & $\begin{array}{l}\text { Roger } 3010 \\
(10.2)\end{array}$ & -15.96 & $\begin{array}{l}18.36 \\
/ \\
6.93\end{array}$ & $\begin{array}{l}\text { Circular/ } \\
\text { Printed } \\
\text { Monopole }\end{array}$ & SKIN & 0.494 \\
\hline [15] & $\begin{array}{l}(40 \times 40 \times 1.59) \\
(1.37 \times 1.37 \times 0.054)\end{array}$ & $1.76 / 4.88$ & $\begin{array}{l}\mathrm{FR}-4 \\
(4.4)\end{array}$ & $\begin{array}{l}-39 / \\
-22.2\end{array}$ & $\begin{array}{l}20.3 \\
\& \\
32.11\end{array}$ & $\begin{array}{l}\text { Linear/ } \\
\text { Monopole }\end{array}$ & SKIN & $\begin{array}{l}\text { Not } \\
\text { Calculated }\end{array}$ \\
\hline [16] & $\begin{array}{l}(3.14 \times 28.6 \times 1.34) \\
(0.082 \times 0.748 \times 0.035)\end{array}$ & $\begin{array}{l}0.402 / \\
2.45\end{array}$ & $\begin{array}{l}\text { Roger } 3010 \\
(10.2)\end{array}$ & $\begin{array}{l}-41 / \\
-21.3\end{array}$ & $\begin{array}{l}41 \& \\
27.8\end{array}$ & $\begin{array}{l}\text { Linear/ } \\
\text { Circular PIFA }\end{array}$ & SKIN & $\begin{array}{l}666 / \\
676\end{array}$ \\
\hline [17] & $\begin{array}{l}(3.14 \times 23 \times 0.634) \\
(0.082 \times 0.60 \times 0.016)\end{array}$ & 2.45 & $\begin{array}{l}\text { Roger } 3010 \\
(10.2)\end{array}$ & -20.3 & $\begin{array}{l}16 \\
18.3\end{array}$ & $\begin{array}{l}\text { Circular/Slotted } \\
\text { Circular Patch }\end{array}$ & MUSCLE & 649 \\
\hline [18] & $\begin{array}{l}3.14 \times 25 \times 1.27) \\
(0.082 \times 0.65 \times 0.033)\end{array}$ & 2.45 & $\begin{array}{l}\text { Roger } 3010 \\
(10.2)\end{array}$ & -17.5 & $\begin{array}{l}8 \\
/ \\
19.1\end{array}$ & $\begin{array}{l}\text { Circular / } \\
\text { Annular Ring }\end{array}$ & MUSCLE & 508 \\
\hline [19] & $\begin{array}{l}(24 \times 22 \times 0.07) \\
(0.36 \times 0.33 \times 0.001)\end{array}$ & 2.45 & $\begin{array}{l}\text { Polyimide } \\
(3.5)\end{array}$ & -19.7 & 24.4 & $\begin{array}{l}\text { Linear / } \\
\text { Monopole }\end{array}$ & SKIN & $\begin{array}{l}0.719 / \\
0.229\end{array}$ \\
\hline $\begin{array}{l}\text { [This } \\
\text { work] }\end{array}$ & $\begin{array}{l}21 \times 13.5 \times 0.254 \\
(0.25 \times 0.16 \times 0.003)\end{array}$ & 2.45 & $\begin{array}{l}\text { Roger RT } 5880 \\
(2.2)\end{array}$ & -15.8 & $\begin{array}{l}47.7 \\
/ \\
53.8\end{array}$ & $\begin{array}{l}\text { Circular / } \\
\text { Simple } \\
\text { Monopole }\end{array}$ & SKIN & 0.78 \\
\hline
\end{tabular}


Table 2

List of parameters of the proposed antenna.

\begin{tabular}{|c|c|c|c|c|c|}
\hline Parameters & Values (mm) & Parameters & Values (mm) & Parameters & Values (mm) \\
\hline Ls & 21 & $\mathrm{I}_{8}$ & 1.5 & w2 & 4.1 \\
\hline $\mathrm{l}_{1}$ & 1.0 & $\mathrm{I}_{9}$ & 1.5 & w3 & 3.0 \\
\hline $\mathrm{I}_{2}$ & 1.0 & $\mathrm{I}_{10}$ & 5.0 & w4 & 6.5 \\
\hline $\mathrm{I}_{3}$ & 8.0 & g & 0.4 & w5 & 8.0 \\
\hline $\mathrm{I}_{4}$ & 1.0 & If & 15 & w6 & 1.5 \\
\hline$I_{5}$ & 1.0 & wf & 0.6 & w7 & 2.0 \\
\hline$I_{6}$ & 1.0 & ws & 13.5 & wg & 10.1 \\
\hline $\mathrm{I}_{7}$ & 1.5 & w1 & 4.0 & wg2 & 8.0 \\
\hline $\lg$ & 8.0 & wg1 & 3.0 & wp & 9.9 \\
\hline G & 7.0 & $S$ & 0.5 & ts & 0.254 \\
\hline Ip & 5.5 & w & 9.9 & & \\
\hline
\end{tabular}

Table 3

Simulated and measured results comparison at $2.45 \mathrm{GHz}$ in free space.

\begin{tabular}{|llllll|}
\hline \multicolumn{3}{|c|}{ Simulated in Free Space } & \multicolumn{3}{c|}{ Measured in Free Space } \\
\hline $\begin{array}{l}\text { Gain } \\
(\mathrm{dB})\end{array}$ & $\begin{array}{l}\text { Imp. BW } \\
(\%)\end{array}$ & $\begin{array}{l}\text { A.R BW } \\
(\%)\end{array}$ & Gain (dB) & $\begin{array}{l}\text { Imp. BW } \\
(\%)\end{array}$ & $\begin{array}{l}\text { A.R BW } \\
(\%)\end{array}$ \\
\hline-2.5 & 5.71 & 47.3 & -2.7 & 8.1 & 35.9 \\
\hline
\end{tabular}

Table 4

Simulated and measured results comparison at $2.45 \mathrm{GHz}$ inside skin.

\begin{tabular}{|llllll|}
\hline \multicolumn{2}{|c|}{ Simulated inside skin } & \multicolumn{3}{c|}{ Measured inside mimicking gel } \\
\hline Gain (dB) & $\begin{array}{l}\text { Imp. BW } \\
(\%)\end{array}$ & $\begin{array}{l}\text { A.R BW } \\
(\%)\end{array}$ & Gain (dB) & $\begin{array}{l}\text { Imp. BW } \\
(\%)\end{array}$ & $\begin{array}{l}\text { A.R BW } \\
(\%)\end{array}$ \\
\hline-13.8 & 46.9 & 55.1 & -15.3 & 47.7 & 53.8 \\
\hline
\end{tabular}

Figures 


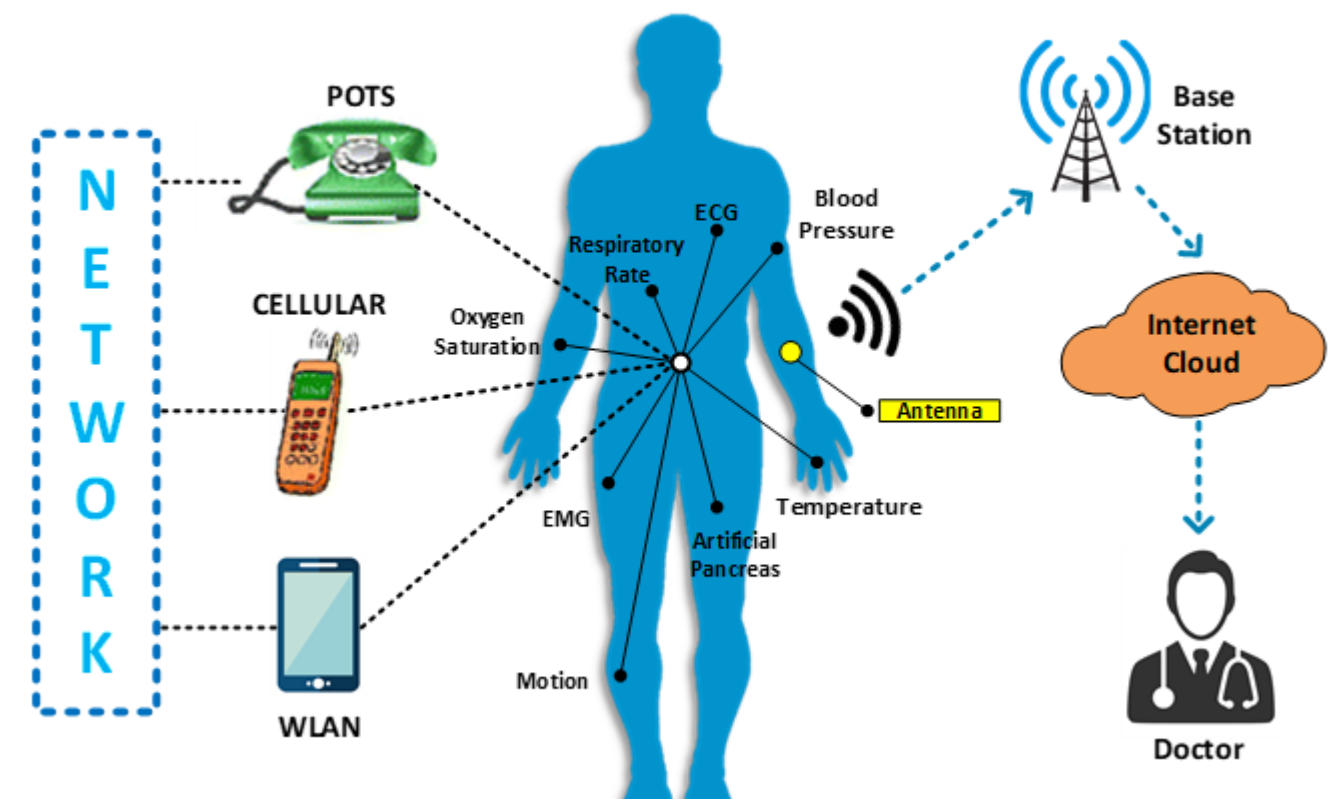

Figure 1

Schematic diagram of the implantable medical devices (IMDs). 


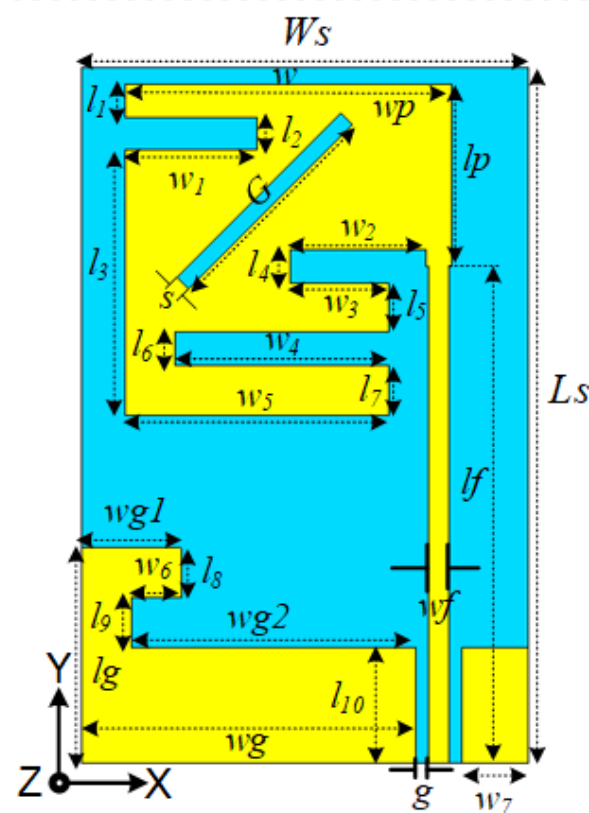

(a)

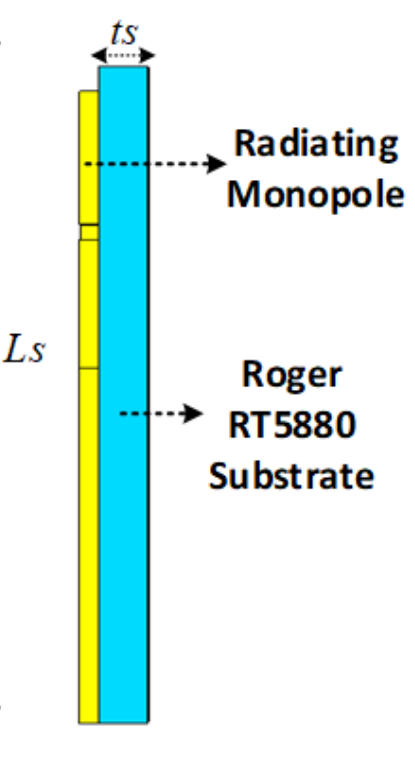

(b)

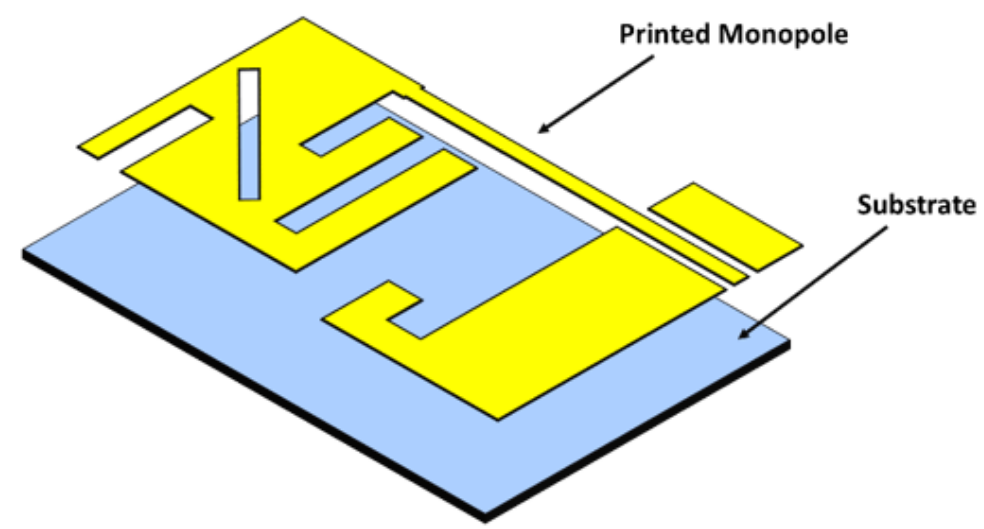

(c)

\section{Figure 2}

Proposed low-profile antenna with dimensions, (a) front view, (b) side view. 


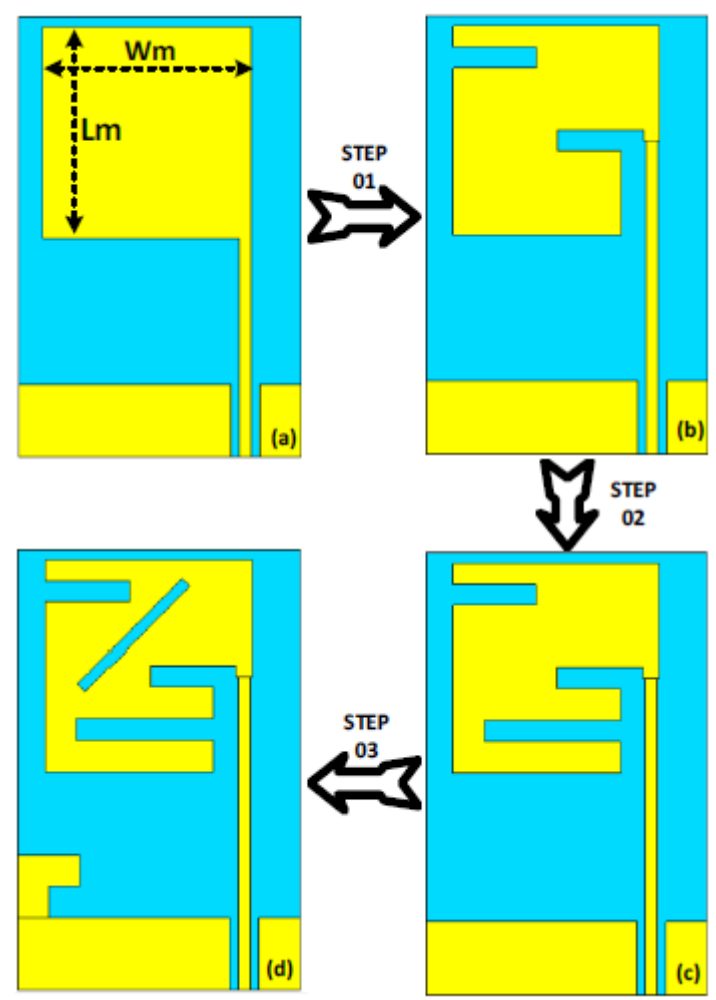

Figure 3

Printed antenna design procedure; (a) rectangular monopole (ANT I), (b) slotted monopole (ANT II), (c) Modified slotted monopole (ANT III), (d) Modified slotted monopole with modified ground plane (ANT IV). (e) Simulation results comparison of S11, (f) Comparison of the axial ratio in $\mathrm{dB}$. 


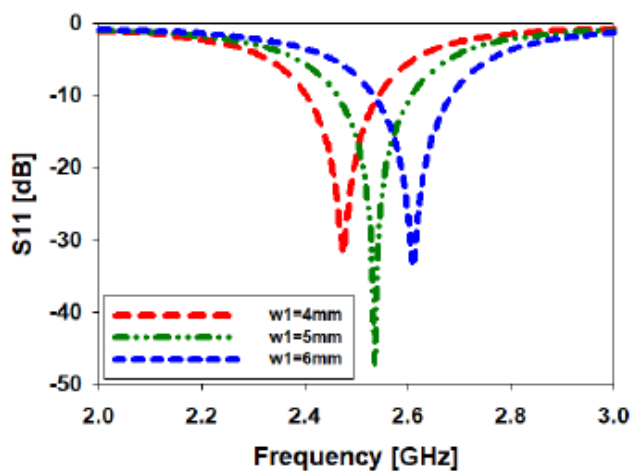

(a)

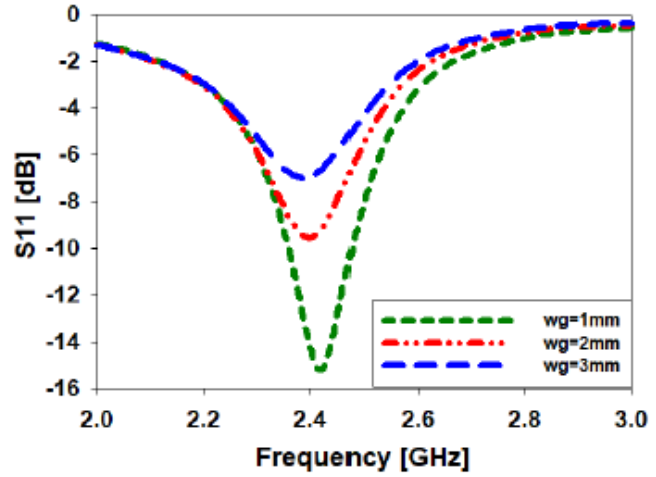

(c)

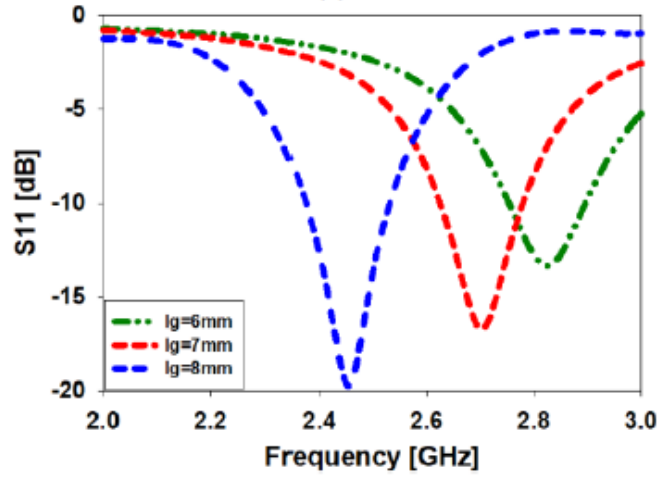

(e)

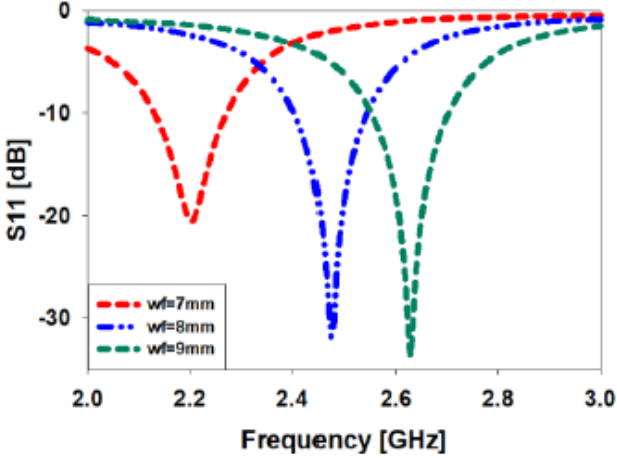

(b)

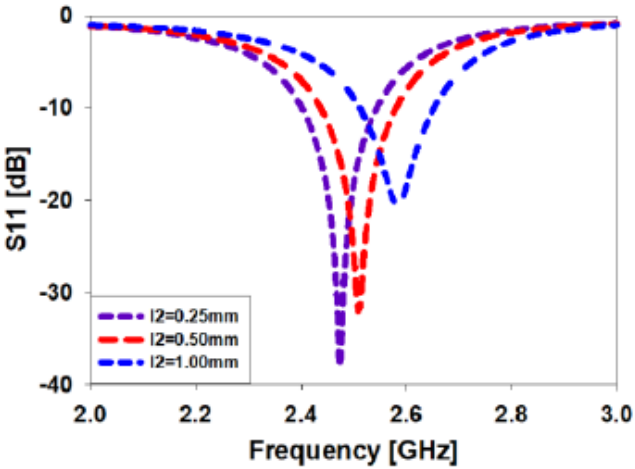

(d)

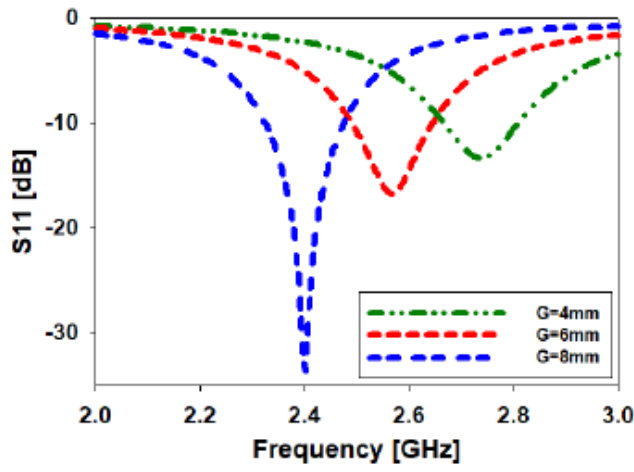

(f)

Figure 4

Parametric study of the antenna; (a) variation in ' $w 1$ ', (b) variation in ' $w f$ ', (c) variation in ' $w g^{\prime}$, (d) variation in 'I2', (e) variation in 'Ig', (f) variation in ' $G$ '.

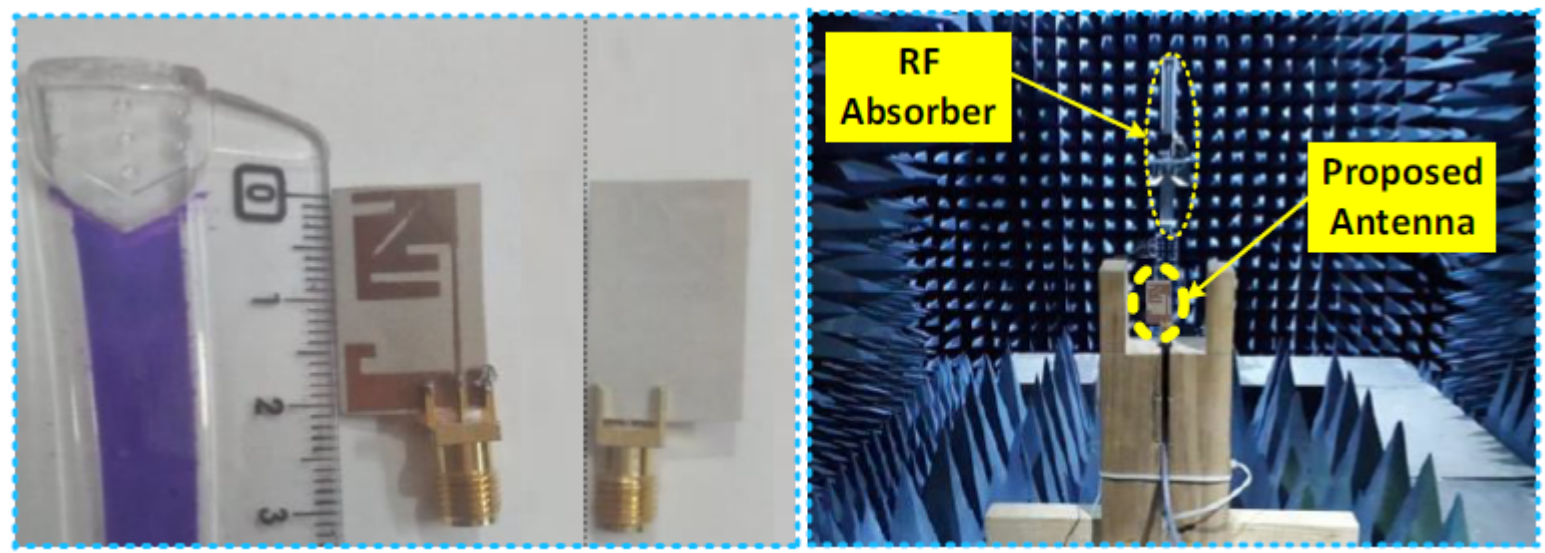

Figure 5

Prototype fabricated antenna; (a) top View, (b) bottom view, (c) antenna setup inside anechoic chamber. 


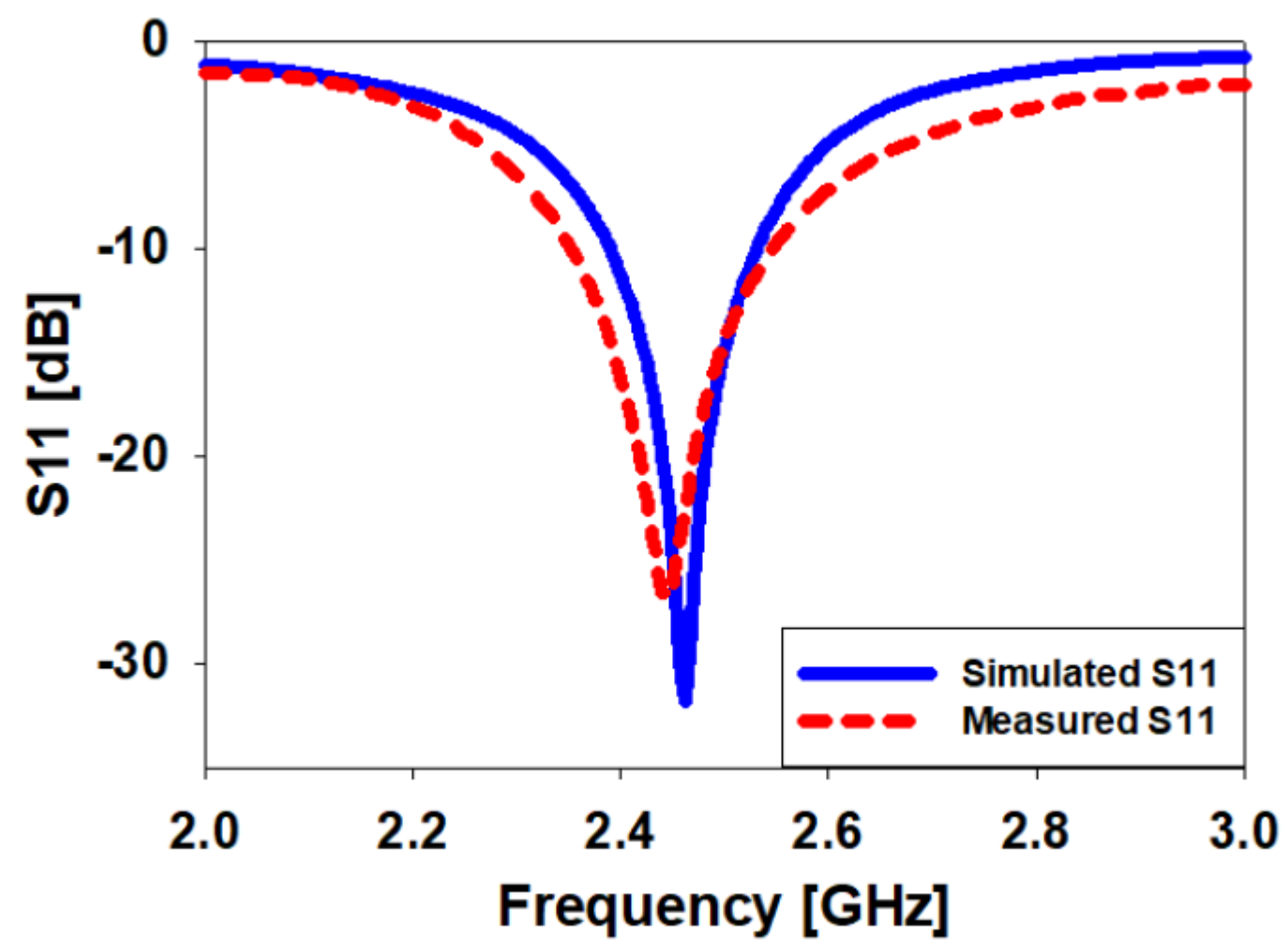

Figure 6

Comparison of the simulation and measurement reflection coefficients [dB] of the prototype printed antenna in free space.
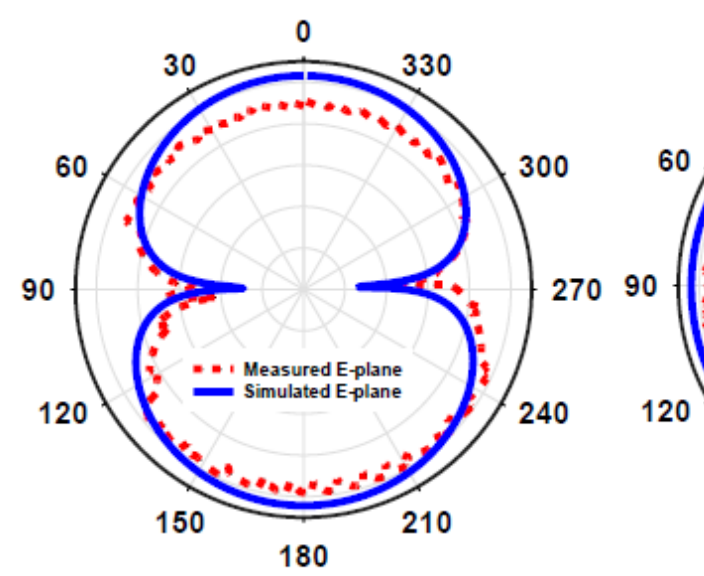

(a)

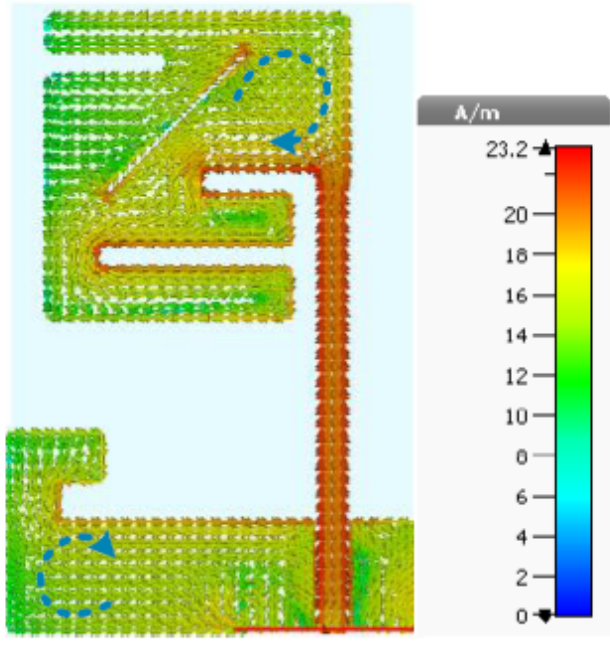

(b)

\section{Figure 7}

2D Radiation pattern of the antenna in free space at $2.45 \mathrm{GHz}$, (b) Current distribution throughout the radiating monopole at $2.45 \mathrm{GHz}$ 

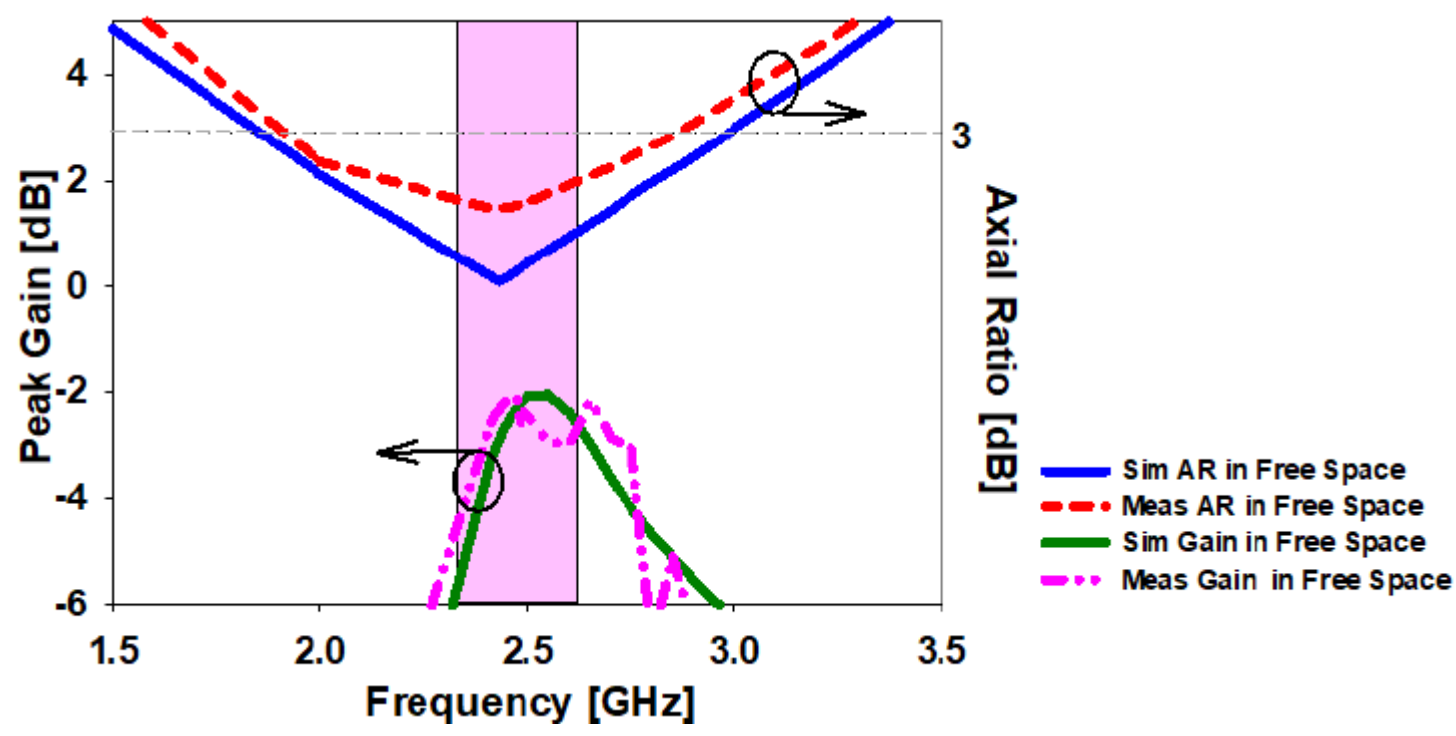

Figure 8

Comparison of the simulated and measured gain and axial ratio of the printed monopole antenna in free space.

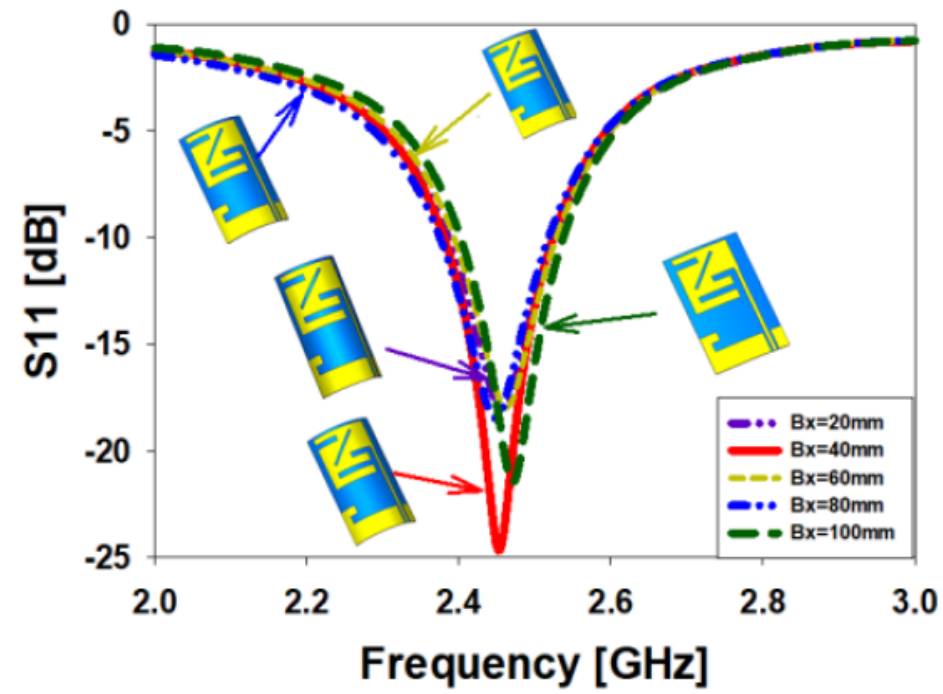

(a)

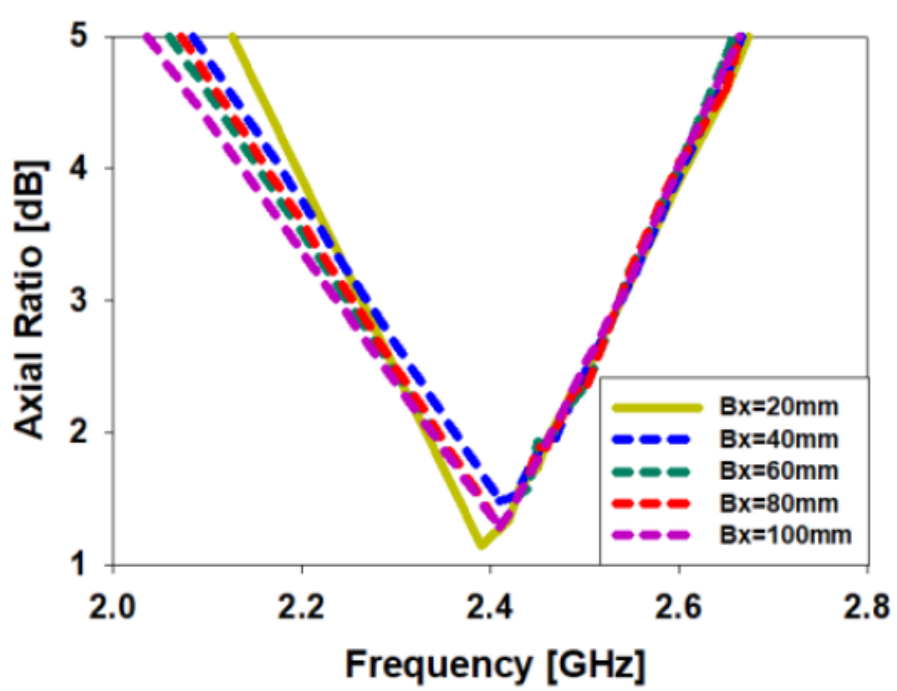

(b)

Figure 9

Bending analysis of the antenna along x-axis at $2.45 \mathrm{GHz},(\mathrm{a})$ Comparison in S11, (b) Comparison in AR. 


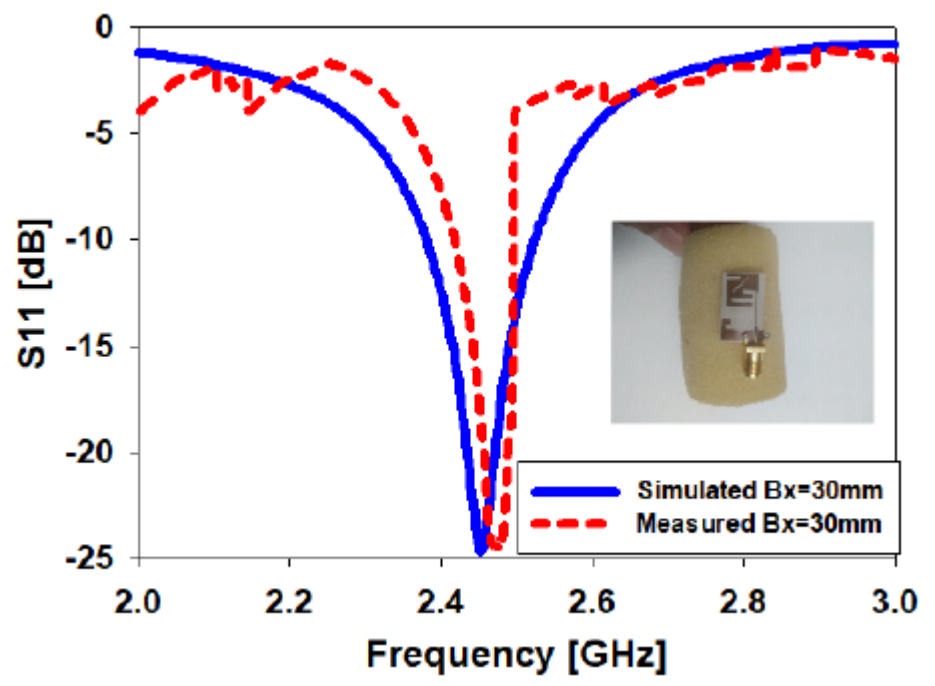

Figure 10

Bending of the antenna and $\mathrm{S} 11$ behavior when bent along $\mathrm{x}$-axis $(\mathrm{Bx}=30 \mathrm{~mm})$.

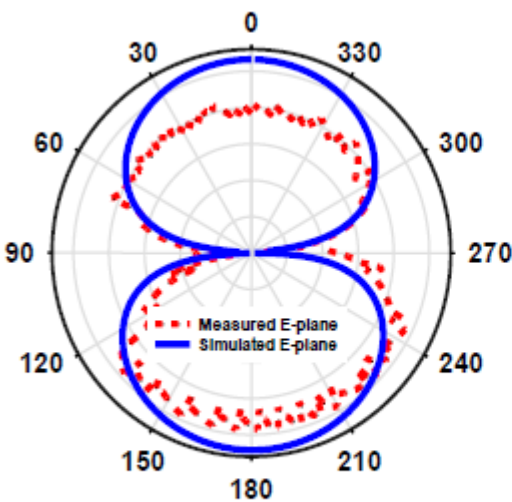

(a)

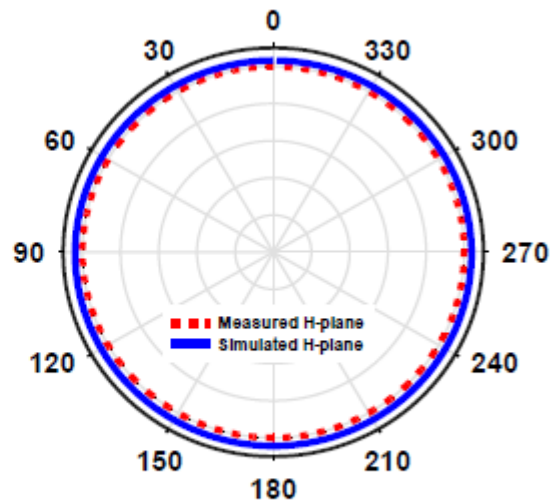

(b)

Figure 11

$2 \mathrm{D}$ radiation pattern of the antenna in free space when the antenna is bent along $\mathrm{x}$-axis $(\mathrm{Bx}=30 \mathrm{~mm})$.

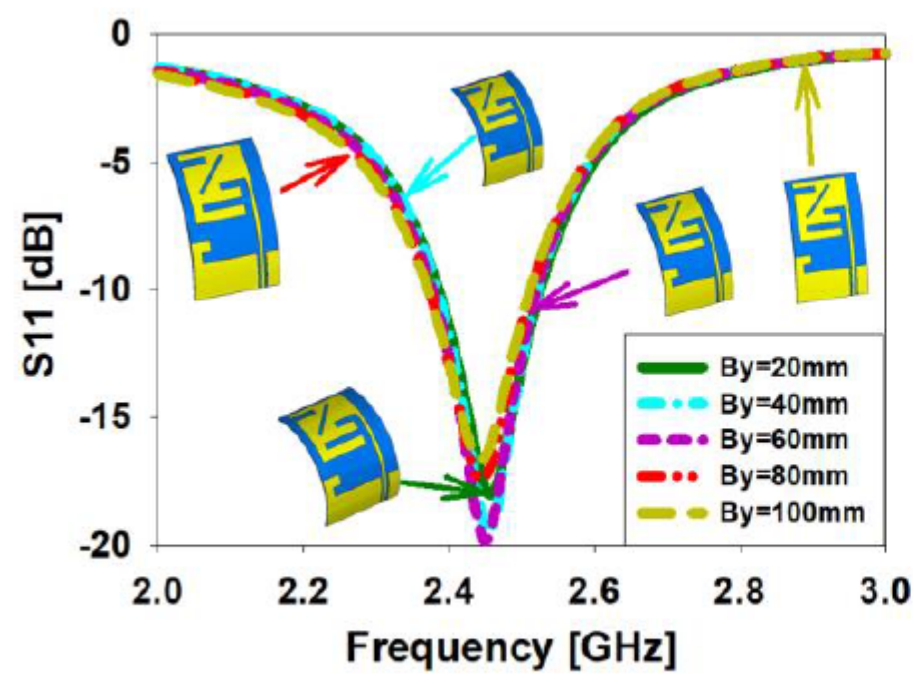

(a)

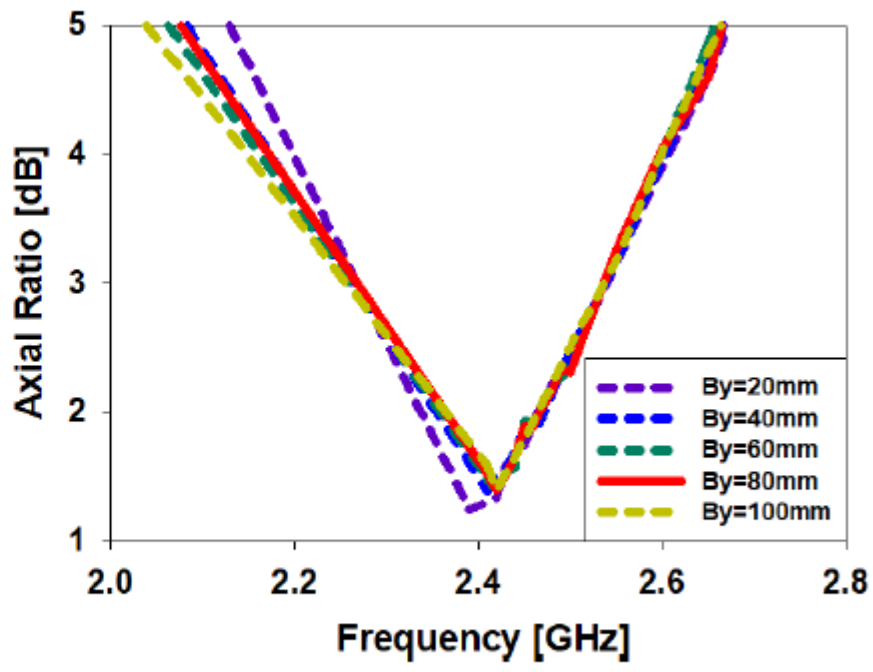

(b) 
Figure 12

Bending analysis of the antenna along y-axis at $2.45 \mathrm{GHz}$, (a) Comparison in S11, (b) Comparison in AR.

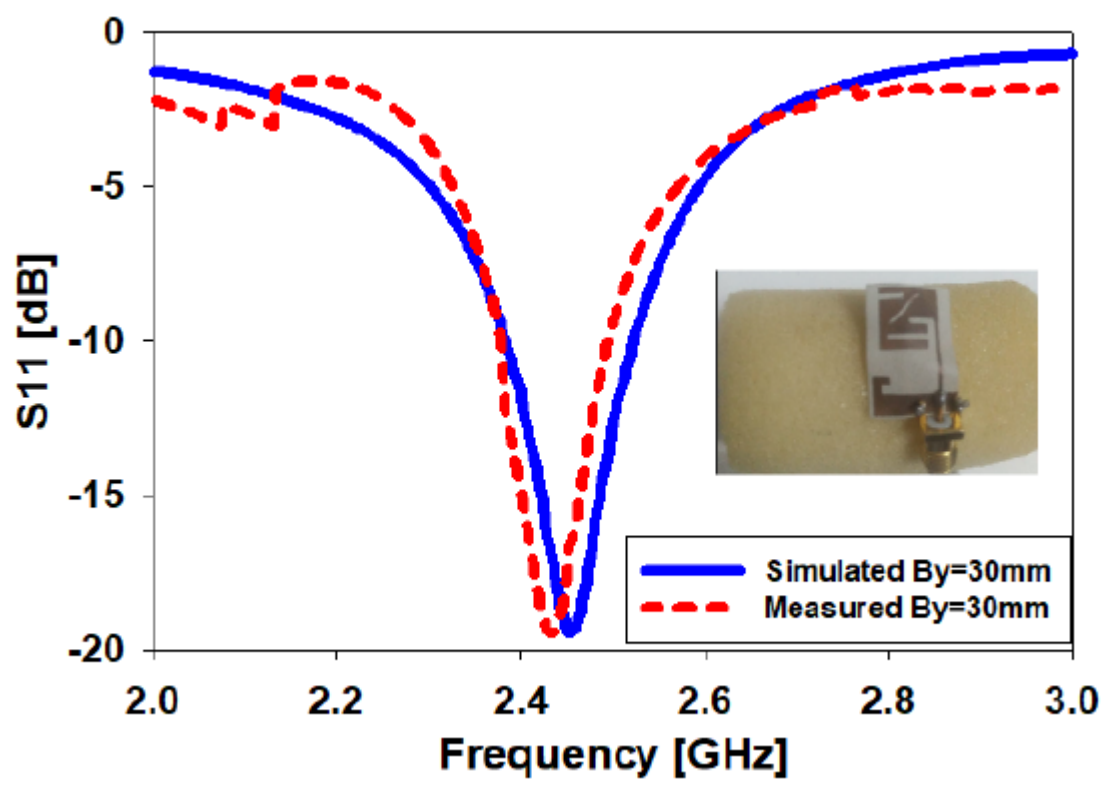

Figure 13

Bending of the antenna and $\mathrm{S} 11$ behavior when bent along $\mathrm{y}$-axis $(\mathrm{By}=30 \mathrm{~mm})$.

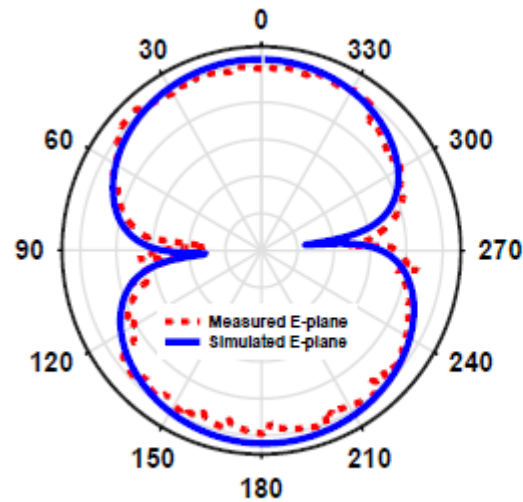

(a)

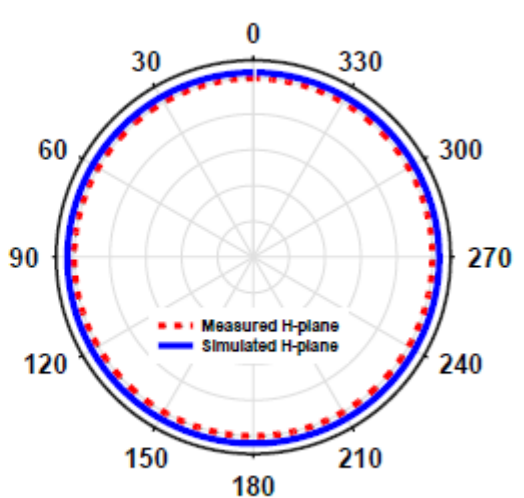

(b)

Figure 14

$2 \mathrm{D}$ radiation pattern of the antenna in free space when the antenna is bent along $y$-axis $(B y=30 \mathrm{~mm})$. 


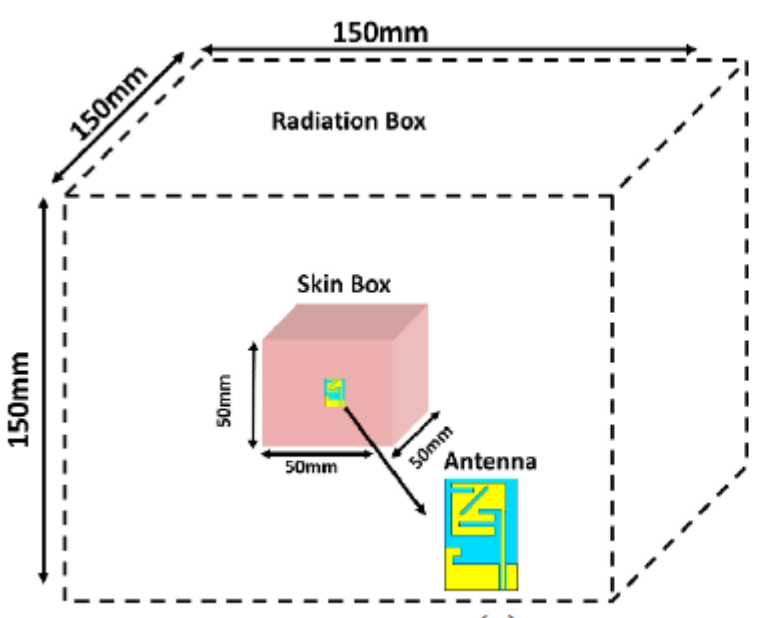

(a)

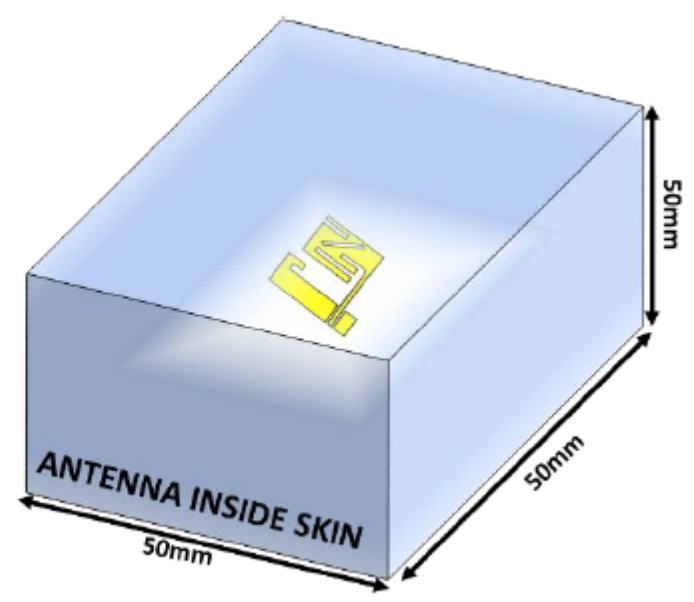

(b)

Figure 15

Human skin phantom box, (a) perspective view, (b) side view.

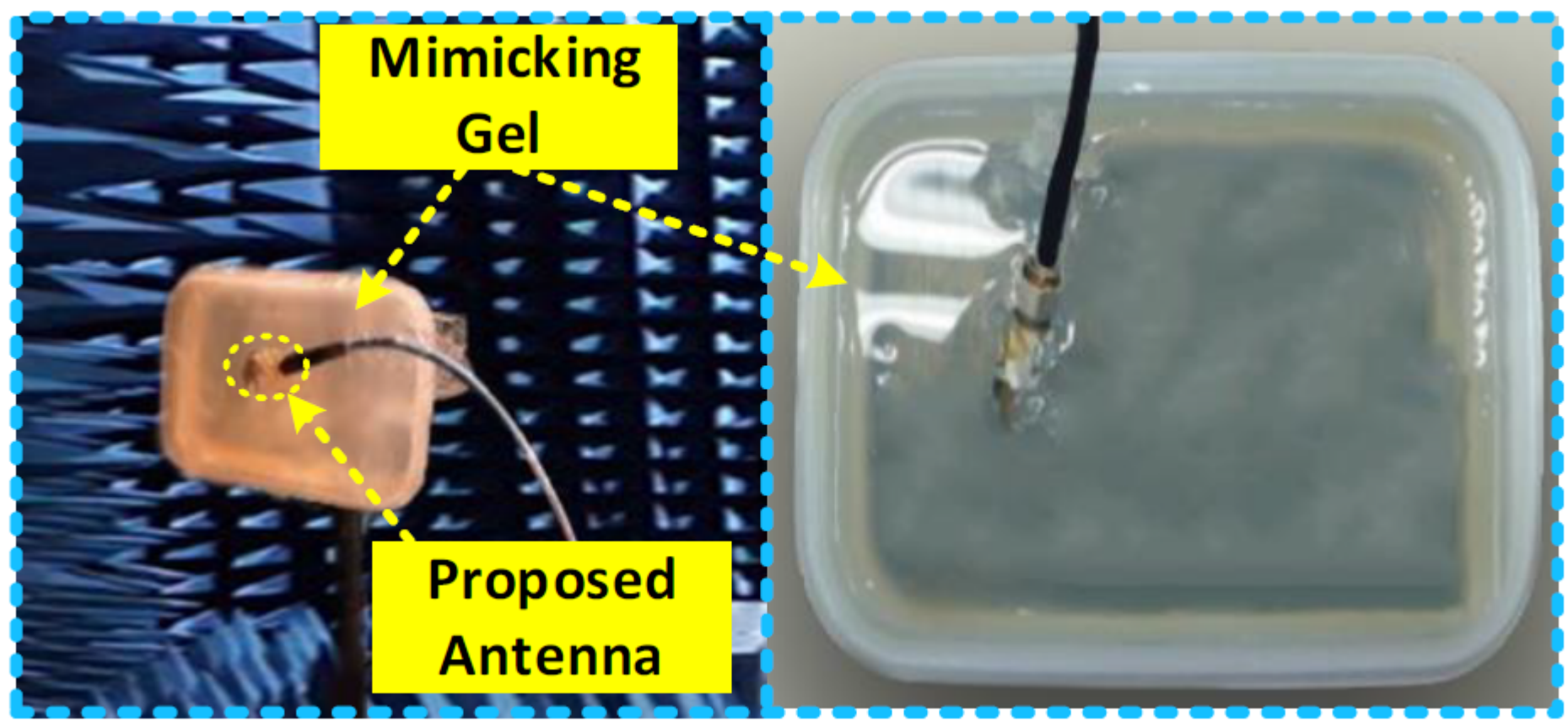

Figure 16

Antenna measurements setup inside 'skin-mimicking gel' of human tissue. 


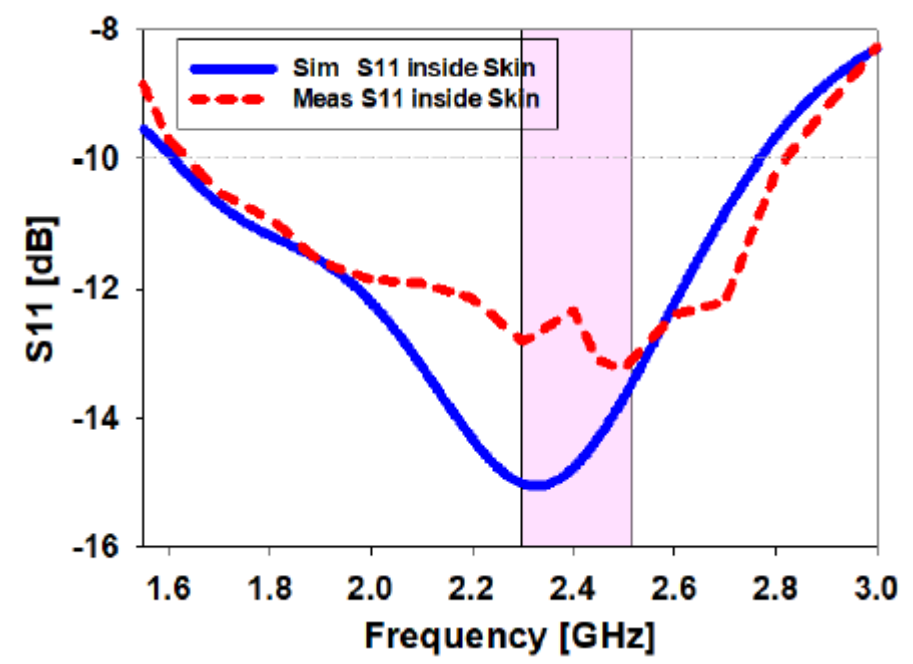

Figure 17

Comparison between the simulated and measured S11 of the antenna inside skin tissue.

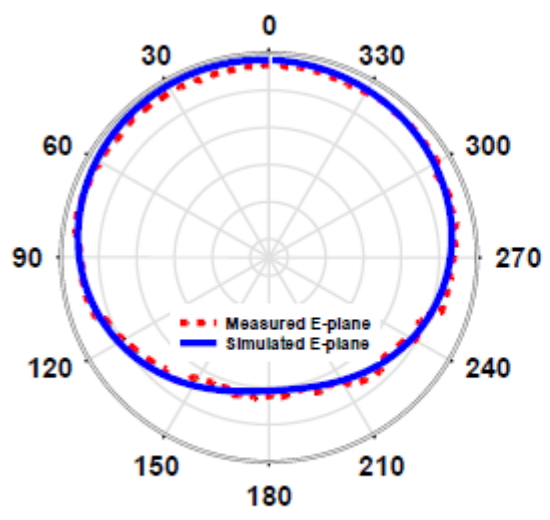

(a)

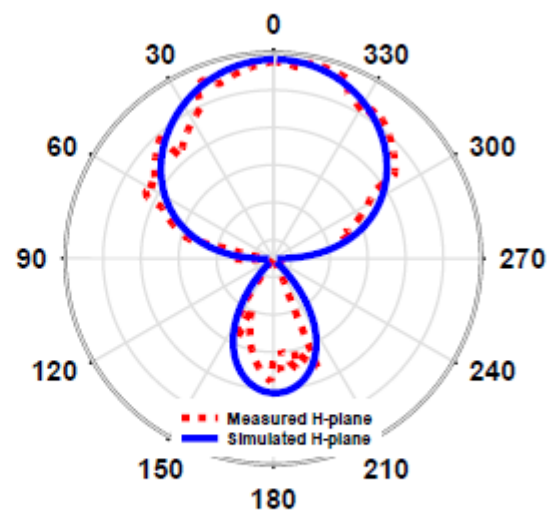

(b)

Figure 18

Simulated and measured farfield results at $2.45 \mathrm{GHz}$ inside skin tissue. 


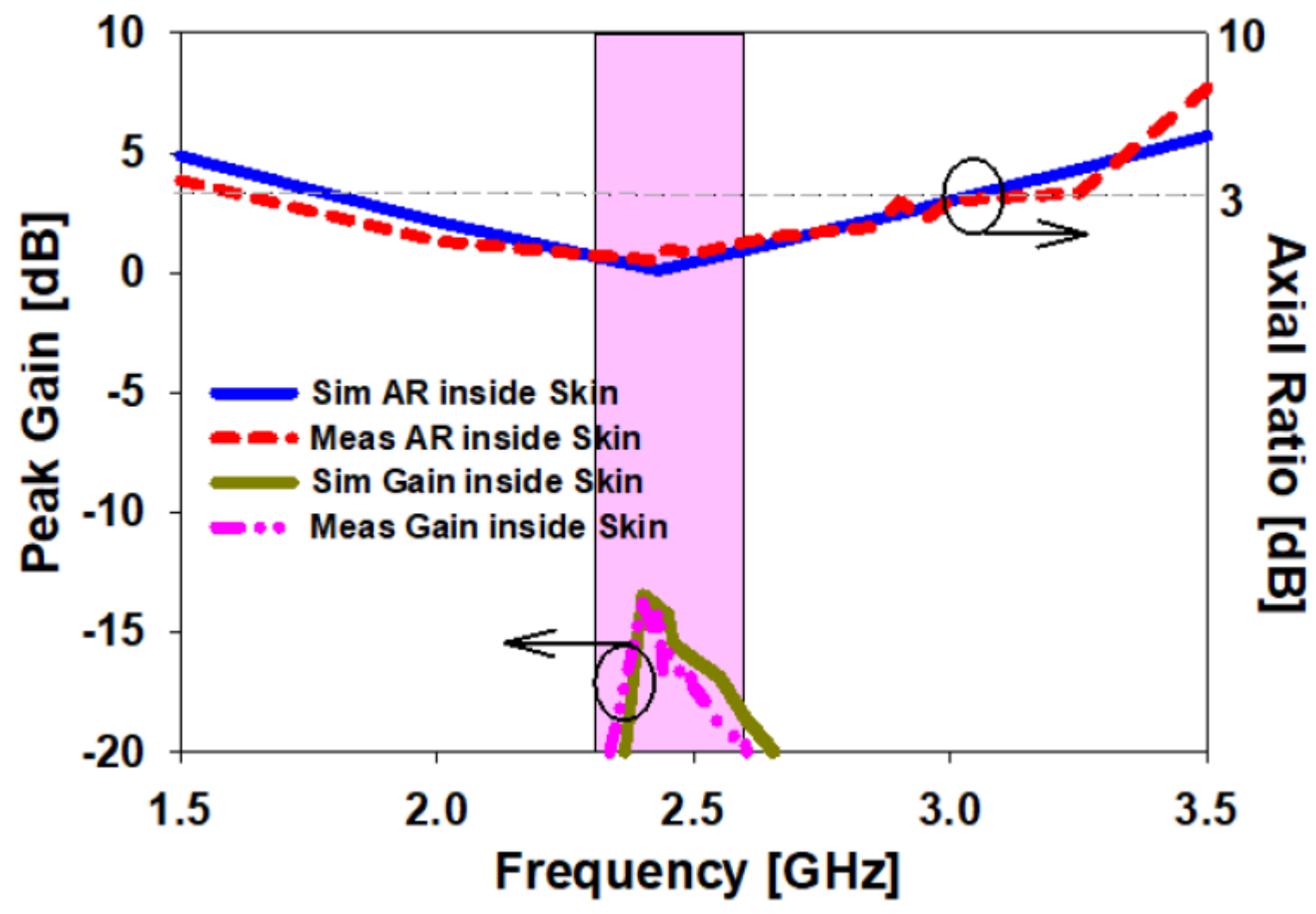

Figure 19

Comparison of the simulation and measurement gain and the axial ratio of the prototype printed antenna inside skin.

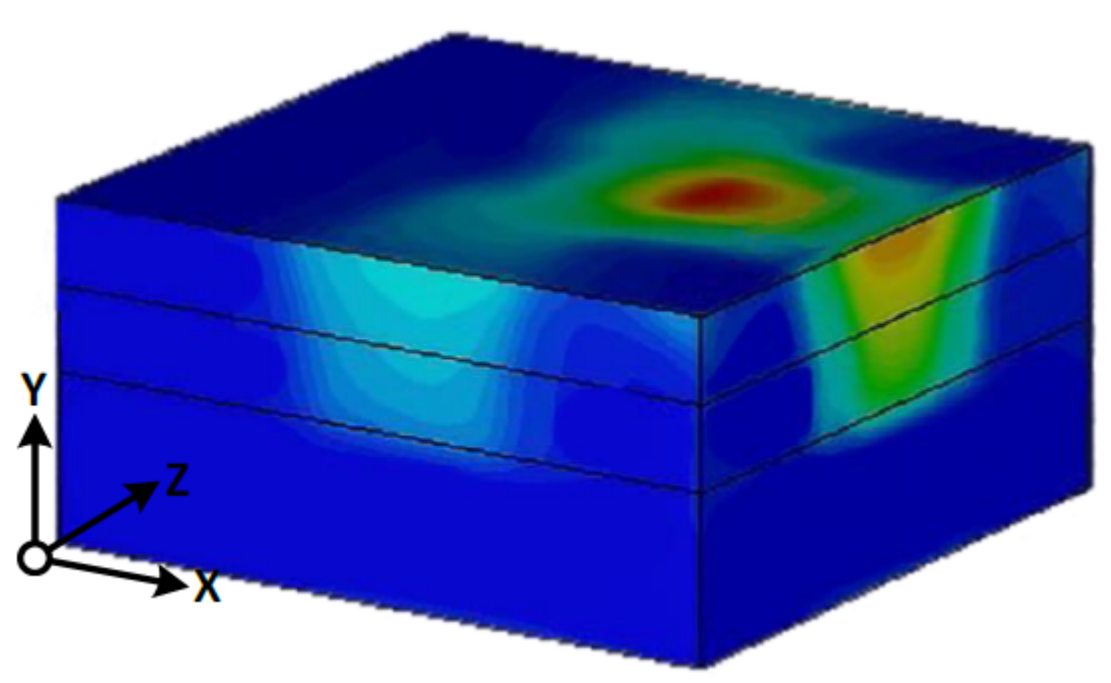

\section{$\mathrm{W} / \mathrm{kg}$}

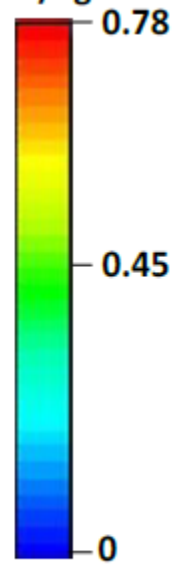

Figure 20

SAR distribution of the proposed antenna inside skin tissue over $1 \mathrm{~g}$ at $2.45 \mathrm{GHz}$. 